\title{
US Food Aid and Civil Conflict
}

\section{Citation}

Nunn, Nathan, and Nancy Qian. 2014. US Food Aid and Civil Conflict. American Economic Review 104, no. 6: 1630-1666. doi:10.1257/aer.104.6.1630.

\section{Published Version}

doi:10.1257/aer.104.6.1630

\section{Permanent link}

http://nrs.harvard.edu/urn-3:HUL.InstRepos:30410811

\section{Terms of Use}

This article was downloaded from Harvard University's DASH repository, and is made available under the terms and conditions applicable to Other Posted Material, as set forth at http:// nrs.harvard.edu/urn-3:HUL.InstRepos:dash.current.terms-of-use\#LAA

\section{Share Your Story}

The Harvard community has made this article openly available.

Please share how this access benefits you. Submit a story.

Accessibility 


\title{
US Food Aid and Civil Conflict
}

\author{
By Nathan NunN AND NANCY QIAN*
}

\begin{abstract}
We study the effect of US food aid on conflict in recipient countries. Our analysis exploits time variation in food aid shipments due to changes in US wheat production and cross-sectional variation in a country's tendency to receive any US food aid. According to our estimates, an increase in US food aid increases the incidence and duration of civil conflicts, but has no robust effect on interstate conflicts or the onset of civil conflicts. We also provide suggestive evidence that the effects are most pronounced in countries with a recent history of civil conflict. (JEL D74, F35, O17, O19, Q11, Q18)
\end{abstract}

We are unable to determine whether our aid helps or hinders one or more parties to the conflict... it is clear that the losses-particularly looted assets-constitutes a serious barrier to the efficient and effective provision of assistance, and can contribute to the war economy. This raises a serious challenge for the humanitarian community: can humanitarians be accused of fueling or prolonging the conflict in these two countries?

- Médecins Sans Frontières, Amsterdam ${ }^{T}$

Humanitarian aid is one of the key policy tools used by the international community to help alleviate hunger and suffering in the developing world. The main component of humanitarian aid is food aid. ${ }^{2}$ In recent years, the efficacy of humanitarian aid, and food aid in particular, has received increasing criticism, especially in the context of conflict-prone regions. Aid workers, human rights observers, and journalists have accused humanitarian aid of being not only ineffective, but of actually promoting conflict (e.g., Anderson 1999; deWaal 1997; and Polman 2010). These qualitative accounts point to aid stealing as one of the key ways in which

\footnotetext{
* Nunn: Department of Economics, Harvard University, 1805 Cambridge Street, Cambridge, MA 02138, NBER, and BREAD (e-mail: nnunn@fas.harvard.edu); Qian: Department of Economics, Yale University, 27 Hillhouse Avenue, New Haven, CT 06520, NBER, BREAD, and CEPR (e-mail: nancy.qian@ yale.edu). A previous version of this paper was circulated with the title: "Aiding Conflict: The Impact of US Food Aid on Civil War." We thank three anonymous referees for comments that substantially improved the paper. We are also grateful to Jenny Aker, David Atkin, Abhijit Banerjee, Chris Blattman, Sylvain Chassang, Ming Chen, Oeindrila Dube, Esther Duflo, Markus Eberhardt, James Fearon, Ray Fisman, Rachel Glennester, Mike Golosov, Anke Hoeffler, Ken Jackson, Michael Kremer, Stelios Michalopoulos, Gerard Padro-i-Miquel, Pepe Montiel Olea, Torsten Persson, Shanker Satyanath, Chris Udry, and David Weil for helpful insights. We thank participants at various conferences and seminars for valuable comments. We also thank Sara Lowes, Eva Ng, and Matthew Summers for valuable research assistance. We acknowledge financial support from the NBER Africa Project. We declare that we have no relevant or material financial interests that relate to the research described in this paper.

${ }^{\dagger}$ Go to http://dx.doi.org/10.1257/aer.104.6.1630 to visit the article page for additional materials and author disclosure statement $(\mathrm{s})$.

${ }^{1}$ Quote from Kahn and Lucchi (2009, p. 22), in reference to operations in Chad and Darfur.

${ }^{2}$ According to data from the US Agency for International Development (USAID), among the countries and years in our sample (non-OECD countries between 1971 and 2006), approximately 30 percent of US economic aid was food aid.
} 
humanitarian aid fuels conflict. They highlight the ease with which armed factions and opposition groups appropriate humanitarian aid, which is often physically transported over long distances through territories only weakly controlled by the recipient government. Reports indicate that up to 80 percent of aid can be stolen en route (Polman 2010, p. 121). Even if aid reaches its intended recipients, it can still be confiscated by armed groups, against whom the recipients are typically powerless. In addition, it is difficult to exclude members of local militia groups from being direct recipients if they are also malnourished and qualify to receive aid. In all these cases, aid ultimately perpetuates conflict.

A large body of qualitative evidence shows that such cases are not rare, but occur in numerous contexts. ${ }^{3}$ Nevertheless, it is difficult to improve the design of aid policy with only anecdotal evidence. For policy makers, a question of first-order importance is whether these accounts reflect extreme cases or are representative of the average effect of humanitarian aid on conflict. We address this integral question by providing causal estimates of the effect of food aid, an important component of humanitarian aid, on conflicts in recipient countries. To the extent that the data allow, we also identify the types of conflicts and contexts that are most affected by food aid.

The main difficulties in identifying the causal effect of food aid on conflict arise from reverse causality and joint determination, both of which bias OLS estimates in directions that are ambiguous ex ante. On the one hand, OLS estimates of the effect of food aid on conflict would be biased upwards if, for example, the presence of conflict increases the demand for food aid. Similarly, an upward bias may result from third factors, such as the occurrences of political and economic crises, that tend to increase both conflict and aid. On the other hand, OLS estimates may be biased downwards if donor governments reduce aid to countries engaged in conflict for political or logistical reasons. In addition, there can be classical measurement error, which would lead to attenuation bias.

The principal contribution of our study is to develop a strategy for estimating the causal effect of US food aid on conflict. Our analysis uses two sources of variation. First, we exploit plausibly exogenous time variation in US wheat production, which is primarily driven by changes in US weather conditions. US agricultural price stabilization policy requires the government to purchase wheat from US farmers at a set price, causing the government to accumulate excess reserves in high production years. Much of the government surplus is then shipped to developing countries as food aid. Thus, US wheat production is positively correlated with US food aid shipments in the following year. Second, we exploit cross-sectional variation in a country's likelihood of being a US food aid recipient, which we measure as the proportion of years that a country receives a positive amount of US food aid during the 36 years of our study, 1971-2006. Using the two sources of variation together, we construct the interaction of last year's US wheat production and the frequency that a country receives any US food aid and use this as an instrument for the amount of food aid received by a country in a given year. Our baseline estimates,

\footnotetext{
${ }^{3}$ As an example, in her recent book, Polman (2010) documents the following examples of large-scale aid theft: Afghanistan (2001-present), Cambodia (1980s), Chad (2008), Ethiopia (1984, 2001-present), Iraq (early 1990s), Kenya (1980s), Nigeria (1967-1979), Rwanda (1994-1996), Sierra Leone (1990s, 2001), South Africa (1990s), Sudan (1982-present), Thailand (1980s), Uganda (1950s), West Timor (1999), and Zaire (1994-1996, 2001).
} 
which examine an annual panel of 125 non-OECD countries, include country fixed effects that control for all time-invariant differences between countries (including the main effect of the likelihood that a country was a US food aid recipient) and region-specific year fixed effects that control for changes over time that affect countries within each region similarly.

Our identification strategy relies on the interaction term being exogenous conditional on the baseline controls. The strategy follows the same logic as a difference-in-differences estimator. To see this, consider the reduced-form estimates, which compare the difference in conflict in years following high US wheat production to years following low US wheat production in countries that regularly receive US food aid relative to countries that rarely receive US food aid.

There are several potential concerns over the excludability of the instrument. First, the underlying driver of the variation in US wheat production, US weather conditions, may be correlated with weather conditions in aid-recipient countries, which can influence conflict through channels other than US food aid. To address this, our baseline regressions directly control for weather conditions in recipient countries. Second, US production changes may be correlated with global wheat prices, which may also affect conflict in recipient countries. In practice, US price stabilization policies mitigate this problem (e.g., global wheat prices are uncorrelated with US wheat production over time). Nevertheless, our baseline estimates control for region-specific year fixed effects to capture region-specific changes in wheat prices over time, as well as controls that account for the possibility that changes in global wheat prices may affect recipient countries differently depending on the extent to which they are producers or importers of cereals.

Our main outcomes of interest are indicator variables that measure the existence of different types of conflict, each with at least 25 battle deaths in a country during the calendar year. We separately examine the incidence of all conflicts, civil conflicts, and interstate conflicts. The OLS estimates of the effect of US food aid on conflict are negative, small in magnitude, and statistically insignificant for all forms of conflict. In contrast, the 2SLS estimates identify a large, positive, and statistically significant effect of US food aid on the incidence of civil conflict, but show no effect on the incidence of interstate conflict. The estimates imply that increasing US food aid by 1,000 metric tons (MT) (valued at $\$ 275,000$ in 2008) increases the incidence of civil conflict by 0.25 percentage points. For a country that receives the sample mean quantity of US food aid of approximately 27,610 MT (\$7.6 million in 2008) and experiences the mean incidence of conflict (17.6 percentage points), our estimates imply that increasing food aid by 10 percent increases the incidence of conflict by approximately 0.70 percentage points. This increase equals approximately 4 percent of the mean incidence of conflict.

The baseline estimates are consistent with the descriptive accounts of humanitarian aid fueling conflict. However, an alternative explanation for our finding is that US food aid crowds out food aid from other countries or other forms of aid (from the United States or other donors). If this were the case, our results would confound the effects of increasing US food aid with the effects of reducing other forms of aid. We investigate this alternative interpretation, which has very different policy implications, and find no evidence of crowd-out. US food aid does not reduce other forms of aid. 
To better understand how food aid can affect conflict, we provide several additional results. First, we show that the effect of food aid is more precisely estimated for small-scale civil conflicts with 25 to 999 combat deaths than for large scale civil wars with 1,000 or more deaths. Second, we show that food aid has little effect on the onset of conflicts, but significantly increases their duration. Finally, we provide suggestive evidence that the adverse effect of food aid is isolated to countries with a recent history of civil conflict. Together, these findings suggest that the primary effect of food aid is to prolong the duration of smaller-scale civil conflicts.

Our findings contribute to several literatures. First, they add to the debate about the effects of foreign aid. $\square^{4}$ Our use of donor-country shocks to instrument for aid provision follows a similar logic as Werker, Ahmed, and Cohen (2009), and Ahmed (2010), who exploit oil price shocks and the fact that oil-rich donors tend to favor Muslim nations to estimate the effects of foreign aid on various macroeconomic outcomes. They find that aid has no effect on economic growth (Werker, Ahmed, and Cohen 2009) and that aid reduces institutional quality (Ahmed 2010). Our finding that aid is partly determined by changes in US domestic production adds to the growing empirical evidence showing that aid is often determined by the strategic or economic needs of donor countries (e.g., Ball and Johnson 1996; Alesina and Dollar 2000; Kuziemko and Werker 2006; and Nunn and Qian 2010). It is also consistent with theoretical and empirical evidence provided by Besley and Persson (2011), as well as with Crost, Felter, and Johnston's (2012) finding of a positive relationship between World Bank funded foreign aid and conflict within the Philippines, and Dube and Naidu's (2010) finding of a positive relationship between US military aid and conflict in Colombia. ${ }^{5}$ Finally, our study is closely related to a large empirical literature, thoroughly reviewed by Blattman and Miguel (2010), that examines the determinants of conflict. ${ }^{6}$

The paper is organized as follows. The following section provides an overview of the anecdotal evidence for the relationship between food aid and conflict, as well as the relationship between US agricultural and aid policies. Section II describes our identification strategy and estimating equations, while Section III describes the data. Section IV presents our baseline estimates, and Sections V and VI explore mechanisms and heterogeneous effects. Section VII offers concluding remarks.

\footnotetext{
${ }^{4}$ The benefit of foreign aid for recipient countries is a much studied and controversial subject. See, for example, Stern (1974); Bauer (1975); Boone (1996); Svensson (1999); Burnside and Dollar (2000); Easterly (2003); Easterly, Levine, and Roodman (2004); and Sachs (2006). For studies focusing specifically on the effects of food aid, see Lavy (1992); Pedersen (1996); Kirwan and McMillan (2007); Levinsohn and McMillan (2007); Quisumbing (2003); and Yamano, Alderman, and Christiaensen (2005).

${ }^{5}$ Not all studies of the effects of foreign aid find that aid increases conflict. Collier and Hoeffler (2002) find that total official development assistance (ODA) has no effect on conflict globally, while de Ree and Nillesen (2009) find that total ODA reduces conflict. The difference in findings across all studies examining foreign aid and conflict is most likely due to either the different empirical strategies or to differences in the types of aid being examined.

${ }^{6}$ Most closely related are Miguel, Satyanath, and Sergenti (2004); Dube and Vargas (2013); and Bruckner and Ciccone (2010), each of whom develop strategies to identify the causal effect of income shocks on civil conflict.
} 


\section{Background}

\section{A. Food Aid and Conflict}

Aid watchers most frequently point to theft by armed factions on the ground as the primary mechanism through which food aid and other types of humanitarian aid promote conflict. Because food aid is regularly transported across vast geographic territories, it is a particularly attractive target for armed factions, especially in countries where the ruling government has limited control outside of the capital. Armed factions can set up road blocks and "tax" aid agencies for safe passage. For example, accounts from Somalia in the early 1990s indicate that between 20 and 80 percent of food aid shipments were either looted, stolen, or confiscated (Barnett 2011, p. 173). The stolen aid was then traded for arms in neighboring Ethiopia (Perlez 1992). In Afghanistan, aid organizations in the province of Uruzgan gave over one-third of their food aid and agricultural support to the Taliban. In Sri Lanka, up to 25 percent of the total value of aid was paid to the Tamil Tigers by Dutch aid workers. In the former Yugoslavia, the UN Refugee Agency (UNHCR) gave 30 percent of the total value of aid to Serbian armed forces, and then more bribes to Croatian forces to pass the respective road blocks in order to reach Bosnia (Polman 2010, pp. 96-104).

The amount of theft can even exceed the value of the food, since convoy vehicles and other equipment are also stolen. In 2008, MSF Holland, an international aid organization working in Chad and Darfur, noted the strategic importance of these goods, writing that these "vehicles and communications equipment have a value beyond their monetary worth for armed actors, increasing their capacity to wage war" (Polman 2010, p. 105).

One of the most well-established cases of humanitarian aid strengthening rebel groups occurred during the Nigeria-Biafra civil war of the late 1960s (Barnett 2011, pp. 133-147). The rebel leader Odumegwu Ojukwu only allowed aid to enter the rebel controlled region of Biafra if it was shipped on his planes. He charged aid agencies for the use of his airplanes and filled the remaining space with arms and other military equipment. The shipments of humanitarian aid allowed Ojukwu to circumvent the siege that had been placed on Biafra by the Nigerian government. The food aid also allowed Ojukwu to feed his army. Many suggest that the shipments of humanitarian aid caused the Biafran civil war to last years longer than it would have otherwise (Polman 2010, pp. 115-119).

In recent years, the most well-known accounts of aid being co-opted by local warlords are from Somalia, where there have been numerous reports of food aid being funneled to the Shabab, a Somali militant group that controls much of Southern Somalia. The Shabab has also demanded that the local offices of the World Food Program pay them a security fee of \$20,000 every six months (MacFarquhar 2010). A recent UN Security Council report writes that "humanitarian resources, notably food aid, have been diverted to military uses. A handful of Somali contractors for aid agencies have formed a cartel and become important power brokers-some of whom channel their profits — or the aid itself_-directly to armed opposition groups" (United Nations Security Council 2010, p. 7).

Aid is not only stolen by rebel militias, but is also appropriated by the ruling government, its military, and government supporters. In other words, both sides of 
civil conflicts can benefit from food aid. In Rwanda, in the early 1990s, government stealing of food aid was so problematic that aid shipments were cancelled on several occasions (Uvin 1998, p. 90). Governments that receive aid often target it to specific populations, excluding opposition groups or populations in potentially rebellious regions. This has been noted to increase hostilities and promote conflict. In Zimbabwe in 2003, the US-based organization, Human Rights Watch, released a report documenting examples of residents being forced to display ZANU-PF Party membership cards before being given government food aid (Thurow and Kilman 2009, p. 206). In eastern Zaire, the leaders of the Hema ethnic group permitted the arrival of international aid organizations only if they agreed to give nothing to their enemies, the Lendu. Polman (2010, p. 10) describes this phenomenon as common, writing that "aid has become a permanent feature of military strategy. Belligerents see to it that the enemy is given as little as possible while they themselves get hold of as much as they can."

Humanitarian aid workers are well aware of the threat of aid theft and have developed a number of strategies for minimizing the amount of theft en route. ${ }^{7}$ However, aid can still fuel conflict even if it is successfully delivered to the intended populations. This is because the recipient populations either include members of rebel or militia groups, or the recipients are "taxed" after receiving the aid. The most well-known example of this occurred in the Hutu refugee camps near Goma following the Rwandan Genocide in 1994. Hutu extremist leaders taxed Hutu civilians in the camps, and transferred the appropriated aid to their militia. The aid and physical protection provided in the refugee camps allowed the Hutu extremists to regroup and rebuild their army. The Hutu militia were then able to carry out raids into Rwanda, which contributed to both the First and Second Congo Wars (Terry 2002, ch. 5; Lischer 2005, ch. 4).

It is important to recognize that there are also a number of potential channels through which food aid may reduce conflict. An obvious example is by spurring economic growth and development. Similarly, if conflicts arise because of resource constraints, aid may reduce conflict by loosening those constraints. Our study estimates the average causal effect of food aid on conflict and, therefore, captures the net effect of all effects (positive and negative) of food aid on conflict.

\section{B. The Determinants of US Food Aid}

Although US food aid is comprised of many different types of food, wheat constitutes the largest proportion of aid. During the period of our study, 1971-2006, 63 percent of all cereal food aid shipments (measured by weight) was wheat, and 58 percent of all food aid shipments was wheat. The United States is the largest donor of food aid in the world, accounting for approximately 58 percent of global food aid in 1990 and 64 percent in 2000 (Barrett and Maxwell 2005, p. 12). ${ }^{8}$ In terms of wheat, the United States provides 68 percent of total shipments during our

\footnotetext{
${ }^{7}$ See, for example, Anderson (1999).

${ }^{8}$ It is followed by the European Union countries, which, in 2000, together accounted for approximately 17 percent of food aid flows. The other major donors are Japan ( 6 percent), Australia ( 3 percent), and Canada ( 3 percent (Barrett and Maxwell 2005, pp. 10-13).
} 
sample period (see online Appendix Table A6). Our study focuses on wheat because of its quantitative importance and because US policies for providing price support to US wheat farmers form the basis of our identification strategy.

An important characteristic of US wheat aid, which is mainly governed by Public Law 480 (PL 480), is the role it plays in providing a use for surplus food production. Within the United States, all forms of food aid are procured by the United States Department of Agriculture (USDA) and administered by either the USDA or USAID. 9 Although food aid shipments are broadly determined by need, since more aid tends to go to more needy countries, on a year-to-year basis, food aid is, to a large extent, determined by US production (Nunn and Qian 2010). The USDA accumulates wheat in high production years as part of its price stabilization policies. The accumulated wheat is stored and then shipped as food aid to poor countries. Given the time lag between harvest, storage, and shipment, wheat harvested in year $t$ tends to arrive in recipient countries in the next calendar year, $t+1$ (Barrett and Maxwell 2005, pp. 149-152). Therefore, in the empirical analysis, we characterize food aid received in year $t$ as a function of US production in year $t-1$.

The amount of food aid shipments to countries each year is the outcome of a complicated set of decisions made by a large number of government agencies (Ball and Johnson 1996). Our empirical analysis assumes that the decision-making process results in accumulated wheat reserves being regularly drawn down through increased shipments of food aid that tend to be given to regular food aid recipients. As we show in Section IV, this assumption is supported by the data.

A significant proportion of the reported value of food aid consists of transportation costs. Using data from 1999-2000, Barrett and Maxwell (2005, pp. 166-168) estimate that only 47 percent of the total value of food aid is the actual value of the commodity itself. The other 53 percent is accounted for by transportation costs. ${ }^{10}$ Since our study is interested in measuring the amount of food aid received by developing countries (net of transportation costs), we will measure food aid as the quantity of food aid shipped rather than its reported value, which includes transportation costs.

\section{Empirical Strategy}

The main challenges for estimating the causal effect of US food aid on the incidence of conflict in recipient countries are the issues of reverse causality and joint determination. In this section, we motivate and describe our empirical strategy for addressing these difficulties.

\footnotetext{
${ }^{9}$ US food aid falls into four broad categories: Title I, Title II, Title III, and other. Title I is administered by the USDA and consists primarily of concessional loans with some grants for commodity exports. Title II and III programs are administered by USAID. Title II programs provide donations to meet humanitarian and development needs. These are typically channeled through either recipient governments, NGOs, or multilateral organizations like the World Food Programme (WFP). Title III aid is sold to developing countries which can be monetized to generate funds for broader development objectives. The final category includes a number of smaller programs including Food for Progress, Section 416(b), Bill Emerson Humanitarian Trust, and International Food for Education and Child Nutrition, all administered by the USDA (Barrett and Maxwell 2005, pp. 20-26). Because the data on the volume of aid is not reported by type, our analysis does not decompose food aid into different categories. In addition, our identification strategy only provides an instrument for total food aid and not for different categories of aid.

${ }^{10}$ Part of the reason for the high shipping costs is that US legislation requires that at least 75 percent of food aid be shipped on US flagged cargo ships that charge inflated rates.
} 
To help understand the variation driving our baseline estimates, first consider the simple case where we use lagged US wheat production (uninteracted) as an instrument for food aid:

$$
\begin{aligned}
& C_{i r t}=\beta F_{i r t}+\mathbf{X}_{i r t} \Gamma+\delta_{r} Y_{t}+\psi_{i r}+\nu_{i r t}, \\
& F_{i r t}=\alpha P_{t-1}+\mathbf{X}_{i r t} \Gamma+\delta_{r} Y_{t}+\psi_{i r}+\varepsilon_{i r t} .
\end{aligned}
$$

Equation (1) is the second stage of our 2SLS system and equation (2) is the first stage. The index $i$ denotes countries, $r$ denotes six geographic regions, and $t$ denotes years. ${ }^{11}$ The sample we analyze is a panel of 125 non-OECD countries between 1971 and 2006.

The dependent variable, $C_{i r t}$, is an indicator variable that equals one if there is conflict in country $i$ during year $t . F_{i r t}$ is the endogenous variable of interest, the quantity of wheat aid shipped from the US to recipient $i$ in year $t . \mathbf{X}_{i r t}$ is a vector of country-year covariates that we motivate and discuss when we present the results. $\delta_{r} Y_{t}$ denotes region-specific time trends and $\psi_{i r}$ denotes country fixed effects. $P_{t-1}$, the amount of US wheat production in the previous year, serves as the instrument. When US production is high, US price stabilization policies generate an accumulation of reserves, which increases the amount of food aid shipped to recipient countries in the subsequent year.

The coefficient of interest, $\beta$, is the estimated effect of an additional unit of US food aid on the incidence of conflict. A positive coefficient, $\hat{\beta}>0$, indicates that, on average, an increase in the provision of US food aid increases the incidence of conflict in the recipient country.

Conceptually, the identification strategy compares conflict in developing countries in years after US wheat production is high to the years after it is low. Causal inference requires the assumption that lagged US wheat production only influences conflict in recipient countries through US food aid (conditional on the baseline controls). A natural concern about the exclusion restriction is that there may be other (nonlinear) changes over time that are spuriously correlated with US wheat production, which may then confound the 2SLS estimates. This concern can be addressed by the inclusion of time-fixed effects. But since the instrument only varies over time, it will be collinear with time fixed effects. Moreover, since changes in US production have larger effects on the aid received by regular aid recipients, we can strengthen the fit of the first stage by allowing for this form of heterogeneity.

To flexibly control for time effects and to improve the strength of the first stage, our baseline estimates use the interaction of lagged US wheat production and a country's propensity to receive food aid from the United States as the instrument for US food aid. Thus, the first and second-stage equations become

$$
\begin{aligned}
& C_{i r t}=\beta F_{i r t}+\mathbf{X}_{i r t} \Gamma+\varphi_{r t}+\psi_{i r}+\nu_{i r t}, \\
& F_{i r t}=\alpha\left(P_{t-1} \times \bar{D}_{i r}\right)+\mathbf{X}_{i r t} \Gamma+\varphi_{r t}+\psi_{i r}+\varepsilon_{i r t} .
\end{aligned}
$$

\footnotetext{
${ }^{11}$ The region classification that we use is taken from the World Bank and consists of the following groups: South Asia, East Asia and Pacific, Europe and Central Asia, Latin America and Caribbean, Middle East and North Africa, and sub-Saharan Africa.
} 
Let $D_{i r t}$ be an indicator variable that takes a value of one if country $i$ receives any US food aid in year $t$. Then, $\bar{D}_{i r}=\frac{1}{36} \sum_{t=1971}^{2006} D_{i r t}$ denotes the fraction of years between 1971 and 2006 that a country receives any US food aid. $\varphi_{r t}$ denotes region-year fixed effects. All other variables are defined as before.

The instrument $P_{t-1} \times \bar{D}_{i r}$ now varies by country and time period, which allows us to control for year fixed effects. We allow the time effects to differ across regions and control for region-year fixed effects, $\varphi_{r t}$, which capture changes over time that affect countries within a region similarly. Note that region-year fixed effects also control for the price of wheat in region $r$ in year $t$. Also note that country fixed effects control for the main effect, $\bar{D}_{i r}$, which is time-invariant.

Conceptually, instrumenting for aid with the interaction term is similar to a difference-in-differences (DD) estimation strategy, where the first-stage estimates compare US food aid receipts in countries that frequently receive US food aid to countries that rarely receive US food aid, in years following high US wheat production relative to years following lower production. The reduced-form estimates make a similar comparison but with conflict as the dependent variable. The main difference between our strategy and a DD strategy is that treatment in our study is measured as a continuous variable.

Causal inference using the interacted instrumental variable relies on the assumption that, conditional on the controls, the interaction between lagged US wheat production and a country's tendency to receive US food aid only affects conflict through the provision of US food aid. The main concern with this assumption is that US wheat production may affect foreign conflict through its influence on the world price of wheat (or other crops that are substitutes or complements to wheat). In practice, this is not a serious problem for our estimates for several reasons. First, the region-year fixed effects in our baseline equation flexibly control for all region-specific changes over time and therefore account for any global or even region-specific price changes. To violate the exclusion restriction, global price changes (arising from US production shocks) would need to have systematically different effects on conflict within regions and in a manner that was correlated with a country's tendency to receive food aid from the United States. Nevertheless, to be cautious, our analysis addresses this possibility with additional controls that capture differential responses of countries to global price changes. We discuss these controls in detail in Section IV. Second, the United States does not dominate global wheat production. For example, in 2000, the United States accounted for 10.3 percent of global wheat production. Finally and most importantly, US price stabilization policies have been quite effective in breaking the link between US wheat production and wheat prices during our period of study. Consistent with this, we find no relationship between total production and average wheat prices measured in real US dollars annually between 1975 and 2006 (the correlation coefficient is 0.003 with a $p$-value of 0.99 ). ${ }^{12}$

\footnotetext{
${ }^{12}$ Data on US wheat prices are from the FAO PriceSTAT (1991-2006) and FAO Price Archive (1973-1990). The figures are the producer price per ton, measured in nominal US dollars. The nominal prices were converted to real prices using the US CPI. We use data from 1975-2006 because 1973 and 1974 are outliers when low US wheat production coincided with the initial OPEC oil shock (October 1973-March 1974) that drastically increased oil and commodity prices. If we examine all years between 1971 and 2006, but omit 1973 and 1974, the correlation coefficient is -0.08 and the $p$-value is 0.64 . When we examine all years from 1971-2006, the correlation coefficient is -0.29 with a $p$-value of 0.09 .
} 
As with all instrumental variable estimates, our 2SLS estimates reflect the average effect for observations that comply with the instrument, i.e., a local average treatment effect (Imbens and Angrist 1994). In our setting, compliers are observations that receive more US food aid following increases in US wheat production. In other words, our instrumental variable estimates are not driven by the effect of US food aid for the countries whose food aid receipts are unaffected by changes in US wheat production over time.

\section{Descriptive Statistics}

Our primary outcome of interest, the incidence of conflict, is constructed using data from the UCDP/PRIO Armed Conflict Dataset Version 4-2010, where a conflict is defined as the use of armed force between two parties that results in at least 25 battle deaths in a year. We examine the occurrence of intrastate conflicts (i.e., civil conflicts), interstate conflicts, and conflicts of all types. An intrastate conflict is defined as a conflict between a government and one or more internal opposition groups, without intervention from other states. An interstate conflict is defined as a conflict occurring between two or more states. The measure of all conflicts includes intra- and interstate conflicts, and also a small number of conflicts labelled by UCDP/PRIO as "extra-systemic" or "internationalized" conflicts. 13

Our measure of US food aid is the amount of wheat aid, measured in thousands of metric tons (MT), shipped to a recipient country in a year from the United States. The data are from the Food and Agriculture Organization's (FAO) FAOSTAT database. By measuring aid in terms of volume, we avoid the difficulty in aid valuation described in Section IB. Data on US wheat production, which is used to construct our instrument, is reported by the USDA. Production is also measured in thousands of metric tons.

Table 1 presents descriptive statistics for the main variables used in our analysis. There are many conflicts in our sample. Approximately 22 percent of observations, which are at the country and year level, experience some form of conflict with most of these being civil conflicts and periods of continued conflict (i.e., there is conflict in the preceding year).

Although US wheat aid is a small part of total US wheat production (5.9 percent on average over the sample period), it can be large from the recipient's point of view. The average ratio of wheat aid received from the United States relative to domestic wheat production among observations in the sample is 2.05 and the average ratio of US wheat aid to domestic cereal production is 0.93 .

The average country in our sample receives some food aid from the United States in 37 percent of the years between 1971 and 2006. For the median country, this figure is 0.30 . Countries range from having never received any food aid from the United States, such as Argentina, Venezuela, and South Africa, to countries that

\footnotetext{
${ }^{13}$ Extra-systemic conflicts are conflicts between a state and non-state group that occurs outside of the government's territory. Internationalized conflicts are conflicts between a state and a non-state group with intervention from another state. There are very few incidences of these two types of conflicts. Our estimates are qualitatively identical if we exclude these conflicts from our measure of the incidence of any conflict.
} 
TABle 1-Descriptive Statistics

\begin{tabular}{lccc}
\hline \hline Variable & Observations & Mean & SD \\
\hline Conflicts (25+ battle deaths): & & & \\
$\quad$ Any conflict & 4,089 & 0.217 & 0.412 \\
Intrastate conflict & 4,089 & 0.176 & 0.381 \\
Interstate conflict & 4,089 & 0.026 & 0.160 \\
Onset of intrastate conflict (all observations) & 4,089 & 0.034 & 0.181 \\
Onset of intrastate conflict (observations that follow no conflict only) & 3,377 & 0.041 & 0.199 \\
Onset of intrastate conflict (hazard model sample) & 1,454 & 0.063 & 0.242 \\
Offset of intrastate conflict (hazard model sample) & 709 & 0.185 & 0.391 \\
& & & \\
US wheat aid (1,000 MT) & 4,089 & 27.61 & 116.61 \\
Frequency of receiving any US food aid & 4,089 & 0.374 & 0.312 \\
Lagged US wheat production (1,000 MT) & 4,089 & 59,053 & 9,176 \\
\hline
\end{tabular}

Notes: An observation is a country and year. The sample includes 125 non-OECD countries for the years 1971-2006.

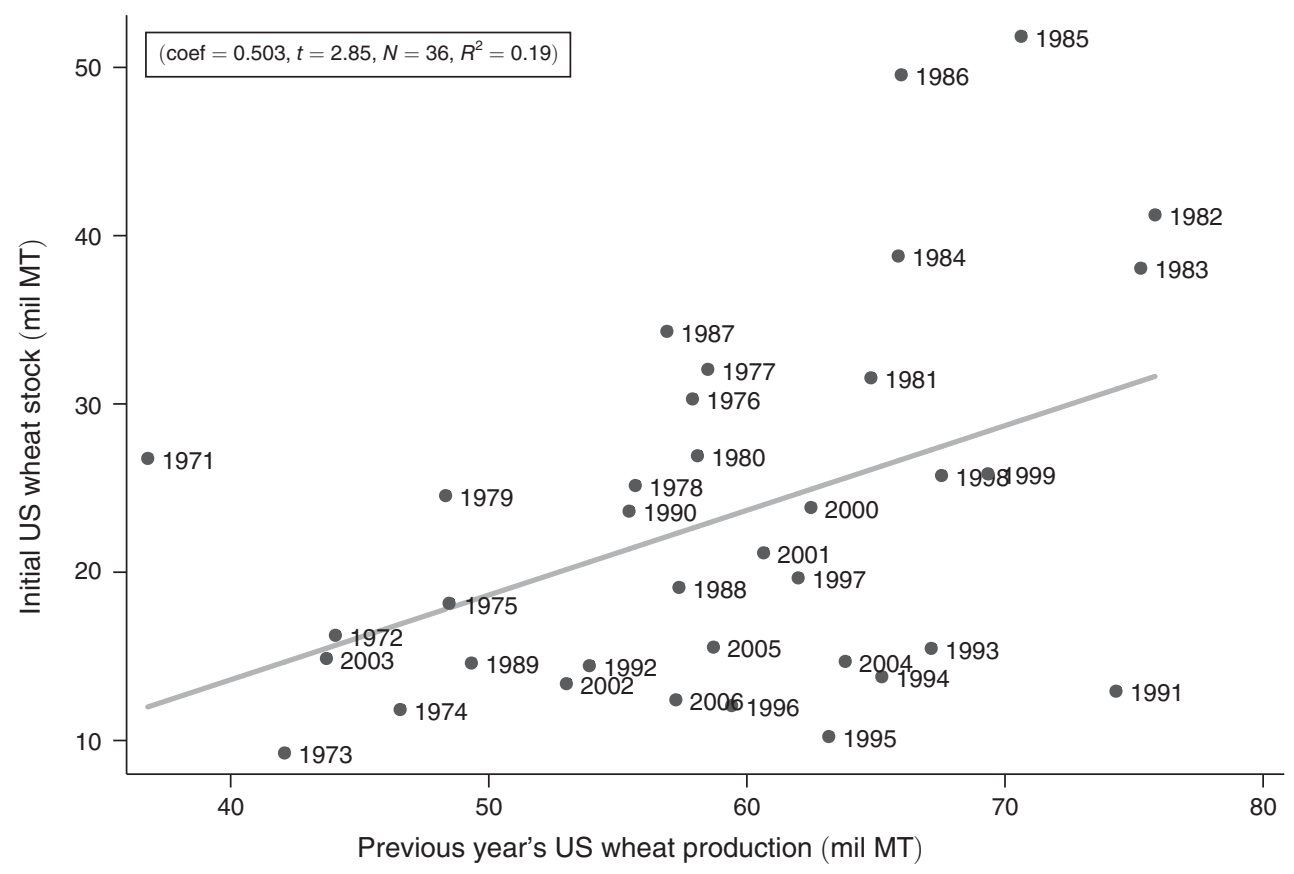

Figure 1. US Wheat Reserves and Lagged US Wheat Production

received some food aid from the United States every year, such as Honduras, Haiti, and Bangladesh. ${ }^{14}$

Our IV strategy exploits the relationship between US aggregate wheat production, the subsequent accumulation of wheat reserves, and shipments of US wheat aid to foreign countries. We test for these links by examining the bivariate relationships between wheat production, accumulated wheat reserves, and wheat aid shipments. Figure 1 shows a strong positive relationship between the total production of

\footnotetext{
${ }^{14}$ For each of the 125 countries in our sample, we report the frequency of receiving food aid from the United States in online Appendix Table A1.
} 


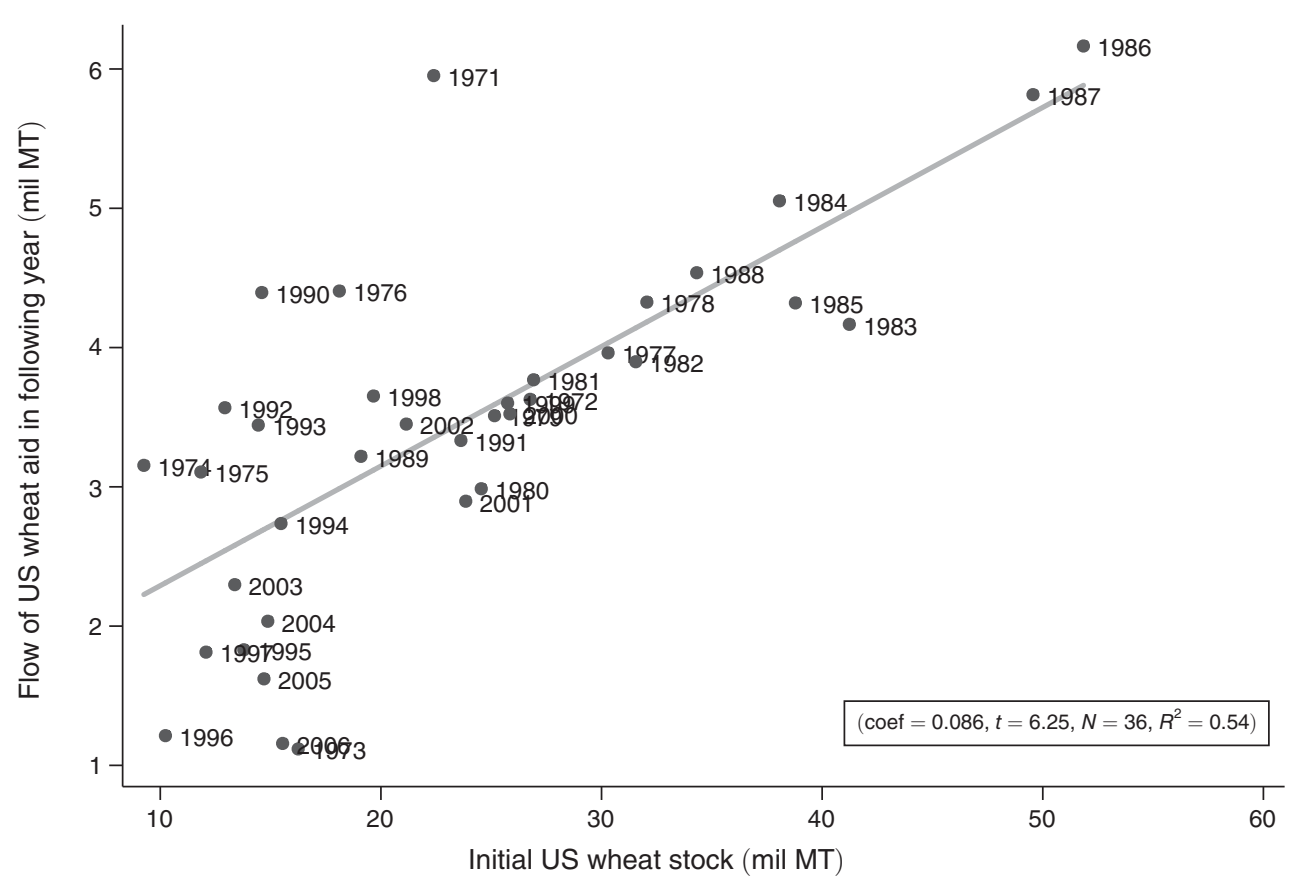

Figure 2. US Wheat Aid and Initial US Wheat Reserves

wheat within the United States and the stock of wheat reserves held by the government at the end of the same year (i.e., at the beginning of the following year). ${ }^{15}$ As shown, more wheat production is followed by a greater accumulation of reserves. Figure 2 shows the relationship between the beginning-of-year wheat reserves and the amount of wheat shipped as food aid in that year. We observe a strong positive relationship. When there is a greater store of reserves at the beginning of the year, more wheat is subsequently shipped as food aid. Together, Figures 1 and 2 show that more production leads to greater reserves, which leads to more food aid being shipped overseas.

We next turn to the reduced form-relationship between US wheat production and conflict in recipient countries, which can also be illustrated visually. We first divide the countries in our sample into two groups based on the frequency with which they receive any US food aid during the sample period. We use the sample median value to create the two equally sized groups, $\bar{D}_{i r} \lessgtr 0.30$, and refer to countries below the median as "irregular" aid recipients and countries above the median as "regular" recipients.

For each group, we calculate the proportion of countries that are engaged in a civil conflict in each year and plot against the one-year lag of US wheat production. Figure 3 shows that there is no correlation over time between lagged US wheat production and conflict incidence among irregular recipients. In contrast, Figure 4 shows that there is a strong positive relationship among regular recipients. Taken

\footnotetext{
period.

${ }^{15}$ Online Appendix Figure A1 shows the year-to-year variation in US wheat production during our sample
} 


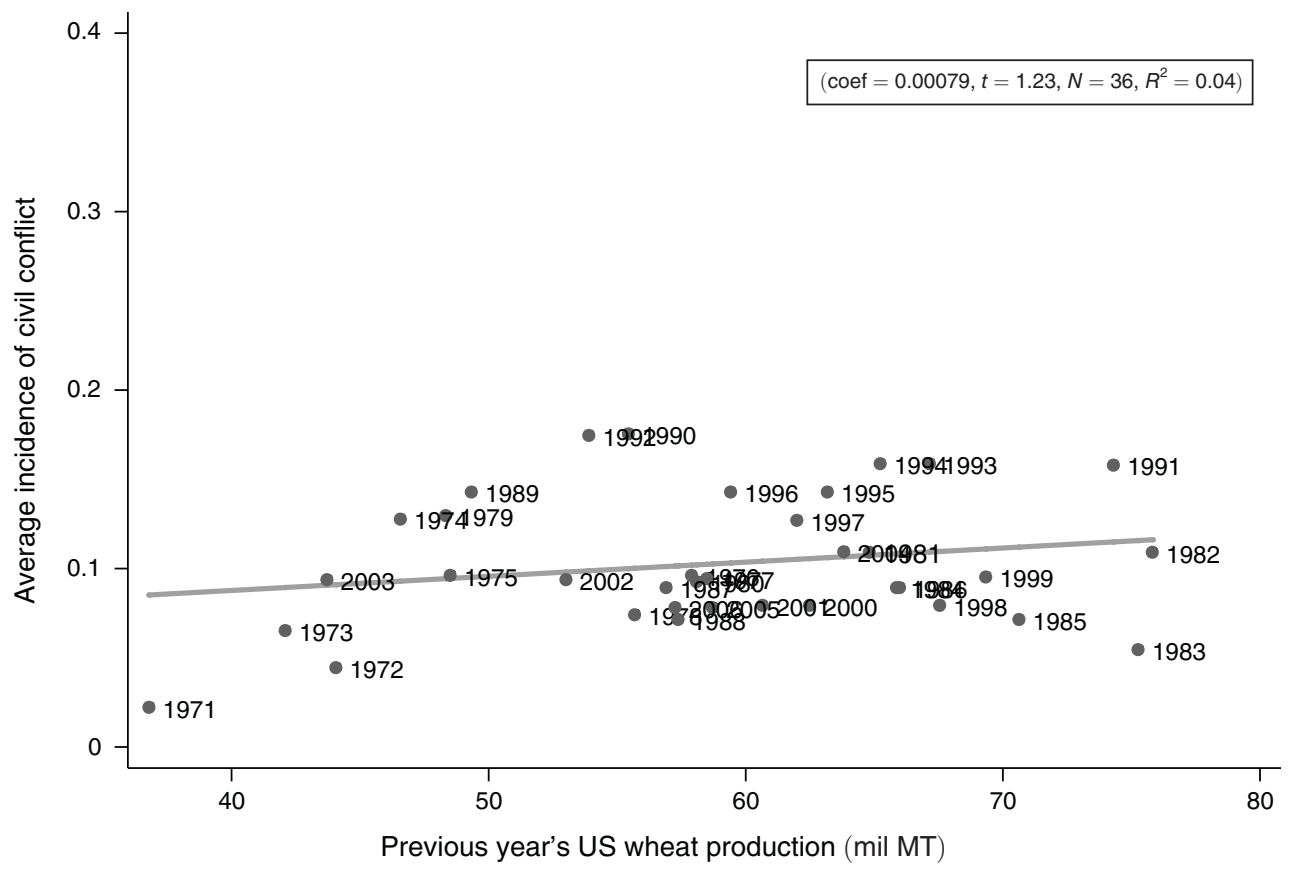

Figure 3. Average Civil Conflict Incidence and Lagged US Wheat Production, Irregular RECIPIENTS: $\bar{D}_{i r}<0.30$

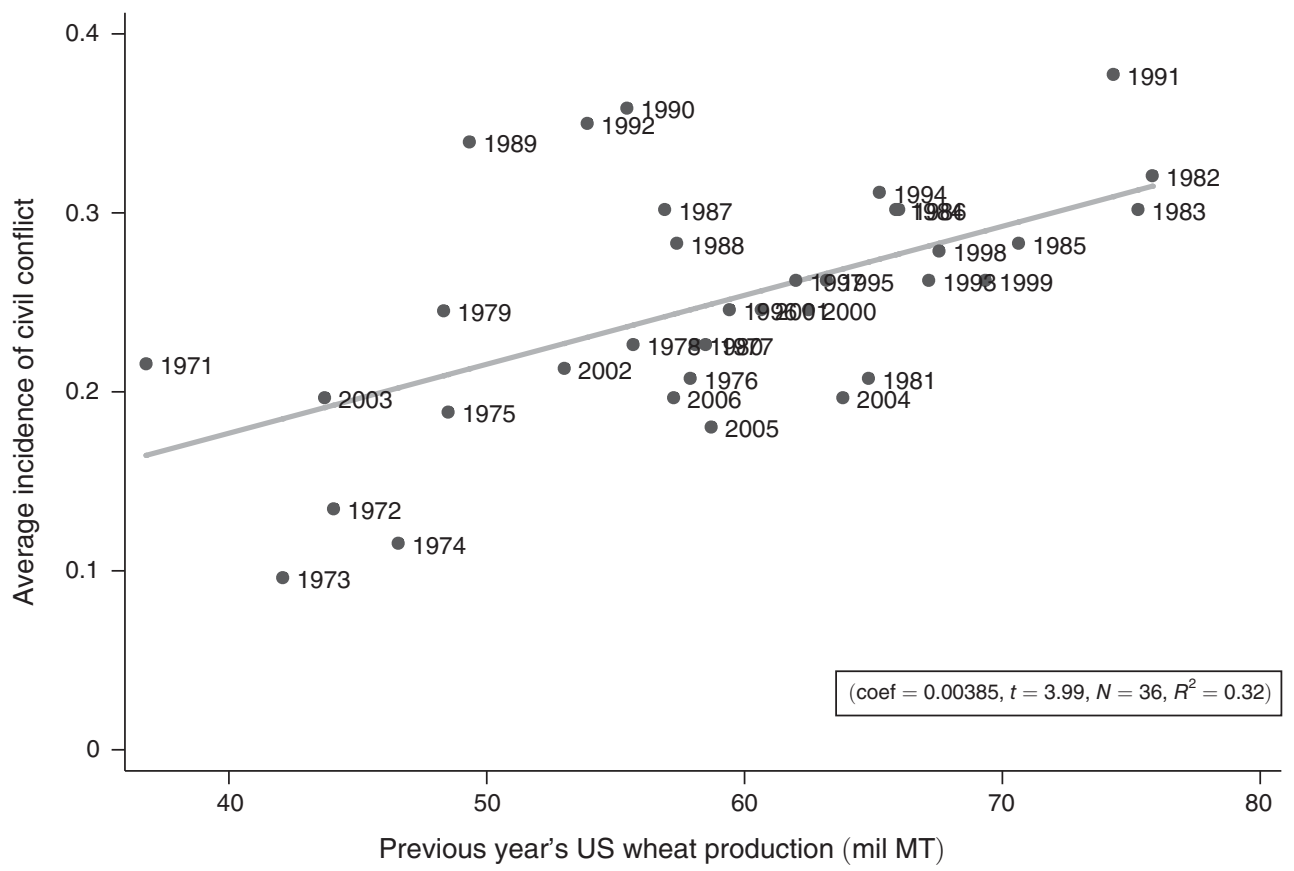

Figure 4. Average Civil Conflict Incidence and Lagged US Wheat Production, Regular RECIPIENTS: $\bar{D}_{i r} \geq 0.30$ 
together, the figures foreshadow our main results by showing that US wheat production is associated with more conflict among regular US food aid recipients but not among irregular recipients. Therefore, they show that the 2SLS estimate of the effect of US food aid on conflict will be positive $(\hat{\beta}>0$ from equation $(3))$ as long as the first-stage estimate is positive in sign $(\hat{\alpha}>0$ from equation $(4))$.

\section{Baseline Estimates}

\section{A. OLS Estimates}

We begin the analysis by first reporting the OLS estimates of equation (3), which are presented in panel A of Table 2. Column 1 reports estimates of the correlation between US food aid and the incidence of any conflict for a specification that only includes recipient-country fixed effects and region-year fixed effects. The estimate is very close to zero and statistically insignificant. In the remaining columns of the table, we include additional covariates to control for factors that may be correlated with conflict, food aid shipments, or US wheat production. We describe these in detail below. The estimates of columns 2-5 show that the OLS relationship between US food aid and the incidence of conflict is unaffected by the inclusion of these additional controls. In columns 6 and 7, we separately investigate the effects on the incidence of civil and international conflicts. We find similarly small and statistically insignificant estimates.

\section{B. First-Stage and Reduced-Form Estimates}

The reduced-form and first-stage estimates of equation (4) are shown in panels B and $\mathrm{D}$ of Table 2. To address a set of natural concerns over the validity of our strategy, we control for a large set of covariates in the baseline specification. We motivate and describe them before presenting the results.

The first concern is that US wheat production may be correlated with factors that have differential influences on the incidence of conflict for countries with different levels of $\bar{D}_{i r}$. Specifically, US wheat production may be correlated with US business cycles, US political cycles, or oil price shocks during the 1970s and 1980s. To address this concern, we control for the following variables in column 2, each interacted with $\bar{D}_{i r}$ : US real per capita GDP, real oil prices, and an indicator that equals one in years that the US president is a Democrat. ${ }^{16}$ Note that the direct (i.e., uninteracted) effects of the variables are captured by the region-year fixed effects.

A second concern is that weather conditions that affect wheat growth in the United States may be correlated with weather conditions in recipient countries, which can directly affect conflict (Miguel, Satyanath, and Sergenti 2004). Therefore, we control for 12 variables that measure the average temperature in each month of year $t$ and 12 variables that measure total precipitation in each month of the same year. By controlling separately for weather in different months, we account for the fact that different parts of the world have different crops with different growing seasons, and

\footnotetext{
${ }^{16}$ The bivariate relationships between each of these measures and lagged US wheat production are reported in online Appendix Table A3.
} 
Table 2-The Effect of Food Aid on Conflict: Baseline Specification with $P_{t-1} \times D_{i r}$ as the Instrument

\begin{tabular}{|c|c|c|c|c|c|c|c|}
\hline \multirow[b]{2}{*}{$\begin{array}{l}\text { Dependent variable } \\
\text { (panels } \mathrm{A}, \mathrm{B} \text {, and } \mathrm{C}) \text { : }\end{array}$} & \multicolumn{4}{|c|}{ Parsimonious specifications } & \multicolumn{3}{|c|}{ Baseline specification } \\
\hline & $\begin{array}{l}\text { Any } \\
\text { conflict } \\
(1)\end{array}$ & $\begin{array}{l}\text { Any } \\
\text { conflict } \\
(2)\end{array}$ & $\begin{array}{l}\text { Any } \\
\text { conflict } \\
\text { (3) }\end{array}$ & $\begin{array}{l}\text { Any } \\
\text { conflict } \\
(4)\end{array}$ & $\begin{array}{c}\text { Any } \\
\text { conflict } \\
(5)\end{array}$ & $\begin{array}{l}\text { Intrastate } \\
(6)\end{array}$ & $\begin{array}{l}\text { Interstate } \\
\quad(7)\end{array}$ \\
\hline \multicolumn{8}{|l|}{ Panel A. OLS estimates } \\
\hline US wheat aid (1,000 MT) & $\begin{array}{c}-0.00006 \\
(0.00018)\end{array}$ & $\begin{array}{r}-0.00007 \\
(0.00018)\end{array}$ & $\begin{array}{c}-0.00005 \\
(0.00017)\end{array}$ & $\begin{array}{r}-0.00007 \\
(0.00017)\end{array}$ & $\begin{array}{c}-0.00011 \\
(0.00017)\end{array}$ & $\begin{array}{c}-0.00005 \\
(0.00017)\end{array}$ & $\begin{array}{c}-0.00011 \\
(0.00004)\end{array}$ \\
\hline$R^{2}$ & 0.508 & 0.508 & 0.518 & 0.534 & 0.549 & 0.523 & 0.385 \\
\hline \multicolumn{8}{|c|}{ Panel B. Reduced form estimates $(\times 1,000) * *$} \\
\hline $\begin{array}{l}\text { Lag US wheat production }(1,000 \mathrm{MT}) \\
\times \text { avg. prob. of any US food aid }\end{array}$ & $\begin{array}{c}0.00829 \\
(0.00257)\end{array}$ & $\begin{array}{c}0.01039 \\
(0.00263)\end{array}$ & $\begin{array}{c}0.01070 \\
(0.00262)\end{array}$ & $\begin{array}{c}0.01133 \\
(0.00318)\end{array}$ & $\begin{array}{c}0.01071 \\
(0.00320)\end{array}$ & $\begin{array}{c}0.00909 \\
(0.00322)\end{array}$ & $\begin{array}{r}-0.00158 \\
(0.00121)\end{array}$ \\
\hline$R^{2}$ & 0.511 & 0.512 & 0.521 & 0.536 & 0.551 & 0.525 & 0.382 \\
\hline \multicolumn{8}{|l|}{ Panel C. 2SLS estimates } \\
\hline US wheat aid $(1,000 \mathrm{MT})$ & $\begin{array}{c}0.00364 \\
(0.00174)\end{array}$ & $\begin{array}{c}0.00303 \\
(0.00125)\end{array}$ & $\begin{array}{c}0.00312 \\
(0.00117)\end{array}$ & $\begin{array}{c}0.00343 \\
(0.00106)\end{array}$ & $\begin{array}{c}0.00299 \\
(0.00096)\end{array}$ & $\begin{array}{c}0.00254 \\
(0.00088)\end{array}$ & $\begin{array}{r}-0.00044 \\
(0.00033)\end{array}$ \\
\hline
\end{tabular}

Dependent variable (panel D):

US wheat aid $(1,000 \mathrm{MT})$

\begin{tabular}{|c|c|c|c|c|c|c|c|}
\hline \multicolumn{8}{|l|}{ Panel D. First-stage estimates } \\
\hline $\begin{array}{l}\text { Lag US wheat production }(1,000 \mathrm{MT}) \\
\times \text { avg. prob. of any US food aid }\end{array}$ & $\begin{array}{c}0.00227 \\
(0.00094)\end{array}$ & $\begin{array}{c}0.00343 \\
(0.00126)\end{array}$ & $\begin{array}{c}0.00343 \\
(0.00120)\end{array}$ & $\begin{array}{c}0.00330 \\
(0.00092)\end{array}$ & $\begin{array}{c}0.00358 \\
(0.00103)\end{array}$ & $\begin{array}{c}0.00358 \\
(0.00103)\end{array}$ & $\begin{array}{c}0.00358 \\
(0.00103)\end{array}$ \\
\hline Kleibergen-Paap $F$-statistic & 5.84 & 7.37 & 8.24 & 12.76 & 12.10 & 12.10 & 12.10 \\
\hline \multicolumn{8}{|l|}{ Controls (for all panels): } \\
\hline Country FE & Yes & Yes & Yes & Yes & Yes & Yes & Yes \\
\hline Region-year FE & Yes & Yes & Yes & Yes & Yes & Yes & Yes \\
\hline $\begin{array}{l}\text { US real per capita GDP } \\
\times \text { avg. prob. of any US food aid }\end{array}$ & No & Yes & Yes & Yes & Yes & Yes & Yes \\
\hline $\begin{array}{l}\text { US democratic president } \\
\times \text { avg. prob. of any US food aid }\end{array}$ & No & Yes & Yes & Yes & Yes & Yes & Yes \\
\hline $\begin{array}{l}\text { Oil price } \times \text { avg. prob. } \\
\text { of any US food aid }\end{array}$ & No & Yes & Yes & Yes & Yes & Yes & Yes \\
\hline $\begin{array}{l}\text { Monthly recipient temperature } \\
\text { and precipitation }\end{array}$ & No & No & Yes & Yes & Yes & Yes & Yes \\
\hline $\begin{array}{l}\text { Monthly weather } \times \text { avg. prob. } \\
\text { of any US food aid }\end{array}$ & No & No & Yes & Yes & Yes & Yes & Yes \\
\hline Avg. US military aid $\times$ year FE & No & No & No & Yes & Yes & Yes & Yes \\
\hline $\begin{array}{l}\text { Avg. US economic aid } \\
(\text { net of food aid }) \times \text { year FE }\end{array}$ & No & No & No & Yes & Yes & Yes & Yes \\
\hline $\begin{array}{l}\text { Avg. recipient cereal imports } \\
\times \text { year FE }\end{array}$ & No & No & No & No & Yes & Yes & Yes \\
\hline $\begin{array}{l}\text { Avg. recipient cereal production } \\
\times \text { year FE }\end{array}$ & No & No & No & No & Yes & Yes & Yes \\
\hline Observations (for all panels) & 4,089 & 4,089 & 4,089 & 4,089 & 4,089 & 4,089 & 4,089 \\
\hline
\end{tabular}

Notes: An observation is a country and a year. The sample includes 125 non-OECD countries for the years 1971-2006. The controls included are indicated in the table by Y (yes) or N (no). Coefficients are reported with standard errors clustered at the country level in parentheses. **In panel B, the point estimates and standard errors are multiplied by 1,000 for presentation purposes. In panel D, we report first-stage Kleibergen-Paap $F$-statistics.

\section{hence, different sensitivities to temperature and precipitation. ${ }^{17}$ We also address the possibility that the relationship between weather and conflict may depend on the}

\footnotetext{
${ }^{17}$ The measures are constructed using country boundaries and monthly weather data measured across grid-cells from the Terrestrial Air Temperature and Precipitation: 1900-2006 Gridded Monthly Time Series, Version 1.10. The database contains daily mean temperature (measured in degrees Celsius) and daily mean precipitation (measured in millimeters) for 0.5 degree by 0.5 degree (approximately $56 \mathrm{~km}$ by $56 \mathrm{~km}$ ) grid-cells globally for each month from 1900 to 2006. For documentation, see, Matsuura and Willmott (2007) and see, Dell, Jones, and Olken (2008) for a recent application.
} 
extent to which a country is a recipient of US food aid. Thus, we also include interactions of the 24 weather controls with $\bar{D}_{i r}$. The estimates are reported in column 3 .

Third, regular recipients of US food aid (i.e., countries with a high value of $\bar{D}_{i r}$ ) could differ from irregular recipients (with a low value of $\bar{D}_{i r}$ ) in ways that are related to conflict. For example, regular recipients tend to also be recipients of US military aid or other forms of US economic aid (besides food aid). ${ }^{18}$ As we report in online Appendix Table A2, countries that are US food aid recipients also tend to receive more economic and military aid from the United States. The country and region-year fixed effects may not control for the effects of US economic and military aid since such aid varies over time and across countries within regions. To address this concern, in column 4, we also control for the interaction of year fixed effects with (i) the average annual amount of per capita US military aid received by a country during the sample period and (ii) the average annual per capita amount of other forms of US economic aid (net of food aid). ${ }^{19}$

Finally, variation in US wheat production can affect international wheat prices, which may, in turn, affect conflict. This concern is mitigated by US price stabilization policies and the inclusion of region-year fixed effects. To be cautious, we nevertheless address the possibility that price changes over time may have differential effects on countries within regions. For example, a country's sensitivity to changes in world prices may depend on the extent to which it imports, exports, and/ or produces wheat or other cereals. Thus, we control for the interaction of year fixed effects with a country's (i) average per capita net imports of cereals over the sample period and (ii) average per capita production of cereals. ${ }^{20}$ These controls allow the effect of global wheat prices to differ across countries depending on the extent to which they produce or import cereals. ${ }^{21}$ Estimates including the additional controls are reported in column 5.

The first-stage estimates in panel D show that there is a strong positive correlation between the instrument and food aid shipments. The first-stage Kleibergen-Paap $F$-statistic for the excluded instrument is 12 in our baseline specification, reported in columns 5 to 7 . Thus, it is very unlikely that our estimates are biased by weak instruments. In terms of magnitude, the estimated coefficient in column 5 suggests that for a country that receives some amount of food aid from the United States each year (i.e., $\bar{D}_{i r}=1$ ), a 1,000 MT increase in US wheat production increases the amount of food aid received in the following year by $3.58 \mathrm{MT}$. As reported in Table 1, the average value of $\bar{D}_{i r}$ in our sample is 0.37 . Therefore, evaluated at the sample mean, a 1,000 MT increase in US wheat production is predicted to increase US food aid shipments by $0.37 \times 3.58=1.34$ MT. Multiplying this by the number of countries,

\footnotetext{
${ }^{18}$ For evidence of the causal effect of economic aid on conflict, see Crost, Felter, and Johnston (2012) and of military aid on conflict, see Dube and Naidu (2010).

${ }^{19}$ Aid data are from the USAID and population data are from the World Bank's World Development Indicators. The figures are measured in 2007 US dollars per person.

${ }^{20}$ Cereal production and cereal imports and exports are from the FAO's ProdSTAT and TradeSTAT databases. Both are measured in thousands of metric tons. Population data are from the World Bank's World Development Indicators.

${ }^{21}$ To address the possibility that cereal imports and production can be outcomes of aid, we do not control for time-varying measures of each variable. Instead, we calculate country averages for each variable and control for the interaction of the country-specific measure with year fixed effects. Estimates from using contemporaneous or oneyear lagged time-varying measures of production and imports, each interacted with year fixed effects are virtually identical to the estimates reported in the paper.
} 
125, gives 167.4 MT, which is an approximate measure of the predicted increase in total US food aid shipments to the world that results from a 1,000 MT increase in US wheat production.

In panel B, the reduced-form effects of our instrument on the outcomes of interest show that US wheat production increases the incidence of civil conflict. The effect of the instrument on the incidence of all conflicts and intrastate conflicts are positive and statistically significant at the one percent level, while there is no effect on interstate conflict. Both the first-stage and reduced-form estimates are stable across the various specifications.

\section{2SLS Estimates}

Panel C of Table 2 reports 2SLS estimates of equation (3). Like the reduced form, the 2SLS estimates remain stable as we introduce the baseline controls in columns 1-5. According to the estimates using the full set of baseline controls reported in column 5, a 1,000 MT increase in US wheat aid increases the incidence of conflict by 0.30 percentage points, an effect that is statistically significant at the one percent level. Columns 6 and 7 show that the effect on overall conflict is driven by an increase in intrastate conflicts and not by interstate conflicts. ${ }^{22}$

The finding that food aid only affects intrastate conflicts is consistent with the descriptive accounts that tend to emphasize the effect of food aid on fueling local conflicts between rebel groups and the government.

To assess the magnitude of the implied 2SLS estimate of the effect of aid on civil conflict, we note that the sample mean of the incidence of civil conflict is 17.6 percentage points (0.176) and the mean of US wheat aid is 27,600 MT. Therefore, for a country at the mean level of US wheat aid, the estimate from column 6 implies that a 10 percent $(2,760 \mathrm{MT})$ increase in US food aid causes a 0.70 percentage point increase in the incidence of civil conflict, which is 4 percent of the sample mean.

To assess the plausibility of this effect, it is useful to compare the magnitude to estimates from other studies. The recent study by Crost, Felter, and Johnston (2012) uses a regression discontinuity design to evaluate the effect of World Bank aid on civil conflict within the Philippines. ${ }^{23}$ The authors estimate that the treatment increases the incidence of conflict during the period when aid is received by 13.2 percentage points (the sample mean of conflict incidence is 49 percent). By comparison, our baseline estimates (e.g., column 6 of Table 2) suggest that sending the average amount of US food aid $(27,600 \mathrm{MT})$ to a country that was previously not receiving any aid would increase conflict by 7.0 percentage points $(27,600 \times 0.00254)$. The comparison shows that the effect of US food aid on conflict in our context is much smaller than the effect of World Bank development aid in the Philippines. ${ }^{24}$ Thus, the magnitude of our estimates are within the range of other causal estimates in the literature.

\footnotetext{
${ }^{22}$ Partial correlation plots for the column 5 estimate are reported in online Appendix Figures A2 and A3. As shown, the positive effect of food aid on conflict is not driven by a small number of influential observations.

${ }^{23}$ Village-level aid in this context is three (sometimes four) disbursements of \$6,000 USD over a seven-year period.

${ }^{24}$ Note that the dollar value of our treatment is much higher than that of Crost, Felter, and Johnston's (2012). The value of a metric ton of wheat in 2009 was approximately $\$ 275$. According to the USDA, the average price in 2008/2009 for No. 1 hard red winter wheat in Kansas City, MO was \$7.50 a bushel, which is equivalent to \$275.55 a
} 


\section{Uninteracted Instrument}

We next turn to our 2SLS equations that use the uninteracted instrument, which are given in equations (1) and (2). The vector of controls, $\mathbf{X}_{i r t}$, includes the time-invariant country controls (i.e., average cereal production, cereal imports, US military aid, and US economic aid), each interacted with a time trend rather than time-period fixed effects; annual measures of US per capita GDP, oil prices, and a Democratic president indicator variable; and the 24 weather variables.

The 2SLS estimates of equation (1), using lagged US wheat production as an instrument, are reported in panel $\mathrm{C}$ of Table 3. Overall, the findings are similar to the baseline estimates reported in Table 2, although the standard errors increase slightly and the point estimates are larger. In addition, the first-stage estimates, reported in panel D, are much weaker than in the baseline specification. For example, the $F$-statistics in columns 5-7 are just above 3. Therefore, in panel C, we also report Anderson-Rubin confidence intervals.

The OLS and reduced-form estimates are reported in panels A and B. The OLS estimates continue to show no relationship between food aid and conflict. The reduced-form estimates show that in years following greater US wheat production, recipient countries experience more conflict.

Together, the estimates from Table 3 show that interacting lagged US wheat production with the regularity that a country receives US food aid does not bias our baseline results relative to using an uninteracted instrument, although it does increase precision.

\section{E. Controlling for Lagged Conflict}

The estimates reported up to this point do not control for lagged conflict. This raises the concern that the baseline specification in equations (3) and (4) do not accurately capture the inherent persistence of conflicts. We therefore model the dynamics of conflict by controlling for one-year lagged conflict.

The estimates, which are reported in Table 4, show that we obtain qualitatively similar results when we condition on lagged conflict. The OLS estimates continue to show no relationship between food aid and conflict, while the 2SLS estimates show a large positive effect. The first-stage estimates show a strong relationship between the instrument and US wheat aid shipments. The long-run effect of the estimated effect of food aid on conflict is slightly larger but similar to the baseline estimates. ${ }^{25}$ Note that controlling for a lagged dependent variable in the fixed effects equation is unlikely to result in the Nickell Bias since our panel contains many time periods. ${ }^{26}$

metric ton. This implies that an increase from no food aid to the sample mean is worth $27,610 \times \$ 275=\$ 7,592,750$ or 7.59 million dollars.

${ }^{25}$ Food aid both has a direct effect, given by $\beta$, and an indirect effect that arises because conflict in this period affects conflict in the next period, which affects conflict in the following period, etc. In the baseline specification, the full effect of a one-time one-unit increase of food aid on intrastate conflict is $\beta$ or 0.00254 (column 6 of Table 2). With a lagged dependent variable (with coefficient $\gamma$ ), the full effect (direct plus indirect) is given by $\beta /(1-\gamma)$, which, according to the estimates from column 6 of Table 4 , is $0.00157 /(1-0.57)=0.00365$.

${ }^{26}$ Consider the formula originally derived by Nickell (1981) for the case without covariates: $\operatorname{plim}_{N \rightarrow \infty}(\hat{\gamma}-\gamma) \simeq \frac{-(1+\gamma)}{T-1}$, where $\gamma$ is the relationship between the dependent variable in period $t$ and the dependent variable in period $t-1$. In our setting, $T=36$ and $\hat{\gamma}=0.57$. Thus, the bias is approximately 
Table 3-The Effect of Food Aid on Conflict: Alternative Specification with $P_{t-1}$ As the Instrument

\begin{tabular}{|c|c|c|c|c|c|c|c|}
\hline \multirow[b]{2}{*}{$\begin{array}{l}\text { Dependent variable } \\
\text { (panels A, B, and C): }\end{array}$} & \multicolumn{4}{|c|}{ Parsimonious specifications } & \multicolumn{3}{|c|}{ Baseline specification } \\
\hline & $\begin{array}{l}\text { Any } \\
\text { conflict } \\
(1)\end{array}$ & $\begin{array}{l}\text { Any } \\
\text { conflict } \\
(2)\end{array}$ & $\begin{array}{l}\text { Any } \\
\text { conflict } \\
(3)\end{array}$ & $\begin{array}{l}\text { Any } \\
\text { conflict } \\
(4)\end{array}$ & $\begin{array}{l}\text { Any } \\
\text { conflict } \\
(5)\end{array}$ & $\begin{array}{l}\text { Intrastate } \\
(6)\end{array}$ & $\begin{array}{l}\text { Interstate } \\
\text { (7) }\end{array}$ \\
\hline \multicolumn{8}{|l|}{ Panel A. OLS estimates } \\
\hline US wheat aid (1000 MT) & $\begin{array}{r}-0.00000 \\
(0.00019)\end{array}$ & $\begin{array}{c}0.00000 \\
(0.00019)\end{array}$ & $\begin{array}{c}0.00000 \\
(0.00019)\end{array}$ & $\begin{array}{c}0.00000 \\
(0.00019)\end{array}$ & $\begin{array}{r}-0.00000 \\
(0.00020)\end{array}$ & $\begin{array}{c}0.00006 \\
(0.00019)\end{array}$ & $\begin{array}{c}-0.00004 \\
(0.00003)\end{array}$ \\
\hline$R^{2}$ & 0.477 & 0.477 & 0.481 & 0.483 & 0.485 & 0.460 & 0.245 \\
\hline \multicolumn{8}{|c|}{ Panel B. Reduced form estimates $(\times 1,000) * *$} \\
\hline $\begin{array}{l}\text { Lag US wheat production } \\
(1,000 \text { MT }) \times \text { avg. prob. } \\
\text { of any US food aid }\end{array}$ & $\begin{array}{c}0.00224 \\
(0.00078)\end{array}$ & $\begin{array}{c}0.00254 \\
(0.00087)\end{array}$ & $\begin{array}{c}0.00254 \\
(0.00086)\end{array}$ & $\begin{array}{c}0.00251 \\
(0.00086)\end{array}$ & $\begin{array}{c}0.00255 \\
(0.00086)\end{array}$ & $\begin{array}{c}0.00183 \\
(0.00081)\end{array}$ & $\begin{array}{c}0.00087 \\
(0.00042)\end{array}$ \\
\hline$R^{2}$ & 0.479 & 0.480 & 0.483 & 0.485 & 0.488 & 0.461 & 0.246 \\
\hline \multicolumn{8}{|l|}{ Panel C. 2SLS estimates } \\
\hline US wheat aid (1,000 MT) & $\begin{array}{c}0.00507 \\
(0.00386)\end{array}$ & $\begin{array}{c}0.00405 \\
(0.00227)\end{array}$ & $\begin{array}{c}0.00366 \\
(0.00205)\end{array}$ & $\begin{array}{c}0.00354 \\
(0.00200)\end{array}$ & $\begin{array}{c}0.00366 \\
(0.00209)\end{array}$ & $\begin{array}{c}0.00263 \\
(0.00160)\end{array}$ & $\begin{array}{c}0.00124 \\
(0.00093)\end{array}$ \\
\hline $\begin{array}{l}\text { Anderson-Rubin confidence } \\
\text { interval }\end{array}$ & $\begin{array}{r}{[0.00186} \\
0.01778]\end{array}$ & $\begin{array}{r}{[0.00156} \\
0.01151]\end{array}$ & $\begin{array}{r}{[0.00155} \\
0.01037]\end{array}$ & $\begin{array}{r}{[0.00148} \\
0.01013]\end{array}$ & $\begin{array}{r}{[0.00165} \\
0.01053]\end{array}$ & $\begin{array}{r}{[0.00088} \\
0.00788]\end{array}$ & $\begin{array}{r}{[0.00288} \\
0.00429]\end{array}$ \\
\hline
\end{tabular}

Dependent variable (panel D): US wheat aid $(1,000 \mathrm{MT})$

\begin{tabular}{|c|c|c|c|c|c|c|c|}
\hline \multicolumn{8}{|l|}{ Panel D. First-stage estimates } \\
\hline $\begin{array}{l}\text { Lag US wheat production } \\
\qquad(1,000 \mathrm{MT})\end{array}$ & $\begin{array}{c}0.000443 \\
(0.000327)\end{array}$ & $\begin{array}{c}0.000670 \\
(0.000359)\end{array}$ & $\begin{array}{c}0.000697 \\
(0.000374)\end{array}$ & $\begin{array}{c}0.000699 \\
(0.000377)\end{array}$ & $\begin{array}{c}0.000696 \\
(0.000380)\end{array}$ & $\begin{array}{c}0.000696 \\
(0.000380)\end{array}$ & $\begin{array}{c}0.000696 \\
(0.000380)\end{array}$ \\
\hline Kleibergen-Paap $F$-statistic & 1.83 & 3.47 & 3.46 & 3.44 & 3.35 & 3.35 & 3.35 \\
\hline \multicolumn{8}{|l|}{ Controls (for all panels): } \\
\hline Country FE & Yes & Yes & Yes & Yes & Yes & Yes & Yes \\
\hline Region-year FE & Yes & Yes & Yes & Yes & Yes & Yes & Yes \\
\hline US real per capita GDP & No & Yes & Yes & Yes & Yes & Yes & Yes \\
\hline US democratic president & No & Yes & Yes & Yes & Yes & Yes & Yes \\
\hline Oil price & No & Yes & Yes & Yes & Yes & Yes & Yes \\
\hline $\begin{array}{l}\text { Monthly recipient temperature } \\
\text { and precipitation }\end{array}$ & No & No & Yes & Yes & Yes & Yes & Yes \\
\hline $\begin{array}{l}\text { Avg. US military aid } \times \\
\text { region-specific time trend }\end{array}$ & No & No & No & Yes & Yes & Yes & Yes \\
\hline $\begin{array}{l}\text { Avg. US economic aid } \times \\
\text { region-specific time trend }\end{array}$ & No & No & No & Yes & Yes & Yes & Yes \\
\hline $\begin{array}{l}\text { Avg. recipient cereal imports } \times \\
\text { region-specific time trend }\end{array}$ & No & No & No & No & Yes & Yes & Yes \\
\hline $\begin{array}{l}\text { Avg. recipient cereal production } \\
\times \text { region-specific time trend }\end{array}$ & No & No & No & No & Yes & Yes & Yes \\
\hline Observations (for all panels) & 4,089 & 4,089 & 4,089 & 4,089 & 4,089 & 4,089 & 4,089 \\
\hline
\end{tabular}

Notes: An observation is a country and a year. The sample includes 125 non-OECD countries for the years 1971-2006. The controls included are indicated in the table by Y (yes) or N (no). Coefficients are reported with standard errors clustered at the country level in parentheses. **In panel B, the point estimates and standard errors are multiplied by 1,000 for presentation purposes. In panel D, we report first-stage Kleibergen-Paap $F$-statistics. In panel C, we report Anderson-Rubin 90 percent confidence intervals.

$\frac{-1(+0.57)}{36}=0.012$ or by 2.1 percent of the value of $\gamma$. This bias is an upper bound since the bias is strictly lower when there are covariates (Nickell 1981). The Nickell bias is further mitigated as it only affects our coefficient of interest indirectly through the first-stage correlation between lagged conflict and food aid, which is low $(\rho=0.09)$. The limited influence of the lagged dependent variable on other covariates of interest when the time dimension is moderately large has also been shown using Monte Carlo simulations by Judson and Owen (1999) and Beck and Katz (2004). 
Table 4-The Effect of Food Aid on Conflict: Controlling for a Lagged Dependent Variable

\begin{tabular}{|c|c|c|c|c|c|c|c|}
\hline \multirow[b]{2}{*}{$\begin{array}{l}\text { Dependent variable } \\
\quad(\text { panels } \mathrm{A}, \mathrm{B} \text {, and } \mathrm{C}) \text { : }\end{array}$} & \multicolumn{4}{|c|}{ Parsimonious specifications } & \multicolumn{3}{|c|}{ Baseline specification } \\
\hline & $\begin{array}{l}\text { Any conflict } \\
\text { (1) }\end{array}$ & $\begin{array}{l}\text { Any conflict } \\
\text { (2) }\end{array}$ & $\begin{array}{l}\text { Any conflict } \\
\text { (3) }\end{array}$ & $\begin{array}{l}\text { Any conflict } \\
\text { (4) }\end{array}$ & $\begin{array}{l}\text { Any conflict } \\
\text { (5) }\end{array}$ & $\begin{array}{l}\text { Intrastate } \\
\quad(6)\end{array}$ & $\begin{array}{l}\text { Interstate } \\
\quad(7)\end{array}$ \\
\hline \multicolumn{8}{|l|}{ Panel A. OLS estimates } \\
\hline US wheat aid (1,000 MT) & $\begin{array}{c}-0.00003 \\
(0.00008)\end{array}$ & $\begin{array}{c}-0.00004 \\
(0.00008)\end{array}$ & $\begin{array}{c}-0.00003 \\
(0.00008)\end{array}$ & $\begin{array}{c}-0.00004 \\
(0.00008)\end{array}$ & $\begin{array}{r}-0.00006 \\
(0.00008)\end{array}$ & $\begin{array}{c}-0.00004 \\
(0.00008)\end{array}$ & $\begin{array}{c}-0.00006 \\
(0.00003)\end{array}$ \\
\hline$R^{2}$ & 0.664 & 0.665 & 0.669 & 0.677 & 0.684 & 0.677 & 0.470 \\
\hline \multicolumn{8}{|c|}{ Panel B. Reduced form estimates $(\times 1,000) * *$} \\
\hline $\begin{array}{l}\text { Lag US wheat production } \\
(1,000 \mathrm{MT}) \times \text { avg. prob. } \\
\text { of any US food aid }\end{array}$ & $\begin{array}{c}0.00435 \\
(0.00144)\end{array}$ & $\begin{array}{c}0.00593 \\
(0.00149)\end{array}$ & $\begin{array}{c}0.00607 \\
(0.00155)\end{array}$ & $\begin{array}{c}0.00688 \\
(0.00204)\end{array}$ & $\begin{array}{c}0.00640 \\
(0.00207)\end{array}$ & $\begin{array}{c}0.00560 \\
(0.00214)\end{array}$ & $\begin{array}{r}-0.00110 \\
(0.00085)\end{array}$ \\
\hline$R^{2}$ & 0.665 & 0.666 & 0.670 & 0.678 & 0.685 & 0.678 & 0.469 \\
\hline \multicolumn{8}{|l|}{ Panel C. 2SLS estimates } \\
\hline US wheat aid (1000 MT) & $\begin{array}{c}0.00187 \\
(0.00088)\end{array}$ & $\begin{array}{c}0.00171 \\
(0.00070)\end{array}$ & $\begin{array}{c}0.00176 \\
(0.00066)\end{array}$ & $\begin{array}{c}0.00207 \\
(0.00067)\end{array}$ & $\begin{array}{c}0.00177 \\
(0.00061)\end{array}$ & $\begin{array}{c}0.00157 \\
(0.00062)\end{array}$ & $\begin{array}{c}-0.00031 \\
(0.00026)\end{array}$ \\
\hline
\end{tabular}

Dependent variable (panel D):

US wheat aid (1,000 MT)

\begin{tabular}{|c|c|c|c|c|c|c|c|}
\hline \multicolumn{8}{|l|}{ Panel D. First-stage estimates } \\
\hline $\begin{array}{l}\text { Lag US wheat production } \\
(1,000 \mathrm{MT}) \times \text { avg. prob. } \\
\text { of any US food aid }\end{array}$ & $\begin{array}{c}0.00233 \\
(0.00103)\end{array}$ & $\begin{array}{c}0.00347 \\
(0.00136)\end{array}$ & $\begin{array}{c}0.00346 \\
(0.00127)\end{array}$ & $\begin{array}{c}0.00332 \\
(0.00098)\end{array}$ & $\begin{array}{c}0.00362 \\
(0.00111)\end{array}$ & $\begin{array}{c}0.00349 \\
(0.00099)\end{array}$ & $\begin{array}{c}0.00357 \\
(0.00109)\end{array}$ \\
\hline Kleibergen-Paap $F$-statistic & 5.07 & 6.52 & 7.36 & 11.53 & 10.67 & 10.77 & 12.35 \\
\hline \multicolumn{8}{|l|}{ Controls (for all panels): } \\
\hline Lagged dependent variable & Yes & Yes & Yes & Yes & Yes & Yes & Yes \\
\hline Country FE & Yes & Yes & Yes & Yes & Yes & Yes & Yes \\
\hline Region-year FE & Yes & Yes & Yes & Yes & Yes & Yes & Yes \\
\hline $\begin{array}{l}\text { US real per capita GDP } \times \text { avg. } \\
\text { prob. of any US food aid }\end{array}$ & No & Yes & Yes & Yes & Yes & Yes & Yes \\
\hline $\begin{array}{l}\text { US democratic president } \times \text { avg. } \\
\text { prob. of any US food aid }\end{array}$ & No & Yes & Yes & Yes & Yes & Yes & Yes \\
\hline $\begin{array}{l}\text { Oil price } \times \text { avg. prob. } \\
\text { of any US food aid }\end{array}$ & No & Yes & Yes & Yes & Yes & Yes & Yes \\
\hline $\begin{array}{l}\text { Monthly recipient temperature } \\
\text { and precipitation }\end{array}$ & No & No & Yes & Yes & Yes & Yes & Yes \\
\hline $\begin{array}{l}\text { Monthly weather } \times \text { avg. } \\
\text { prob. of any US food aid }\end{array}$ & No & No & Yes & Yes & Yes & Yes & Yes \\
\hline $\begin{array}{l}\text { Avg. US military aid } \times \\
\text { year FE }\end{array}$ & No & No & No & Yes & Yes & Yes & Yes \\
\hline $\begin{array}{l}\text { Avg. US economic aid (net } \\
\text { of food aid) } \times \text { year FE }\end{array}$ & No & No & No & Yes & Yes & Yes & Yes \\
\hline $\begin{array}{l}\text { Avg. recipient cereal imports } \\
\quad \times \text { year FE }\end{array}$ & No & No & No & No & Yes & Yes & Yes \\
\hline $\begin{array}{l}\text { Avg. recipient cereal } \\
\text { production } \times \text { year FE }\end{array}$ & No & No & No & No & Yes & Yes & Yes \\
\hline Observations (for all panels) & 4,071 & 4,071 & 4,071 & 4,071 & 4,071 & 4,071 & 4,071 \\
\hline
\end{tabular}

Notes: An observation is a country and a year. The sample includes 125 non-OECD countries for the years 1971-2006. The controls included are indicated in the table by Y (yes) or N (no). Coefficients are reported with standard errors clustered at the country level in parentheses. **In panel B, the point estimates and standard errors are multiplied by 1,000 for presentation purposes. In panel D, we report first-stage Kleibergen-Paap $F$-statistics.

\section{F. Falsification Tests}

In this section, we provide additional evidence for the validity of our identification strategy by undertaking two falsification tests. In the first test, we estimate our reduced-form equation, but instead of examining the link between US wheat production and conflict, we examine the relationship between US production of food crops that are not used as food aid. If our identification strategy is valid, then US 
Table 5-Reduced-Form Estimates of the Effect of Placebo Instruments on Civil Conflict

\begin{tabular}{|c|c|c|c|c|c|c|}
\hline & \multicolumn{6}{|c|}{ Reduced-form estimates $(\times 1,000) * *$. Dependent variable: Incidence of civil conflict } \\
\hline & \multirow{2}{*}{$\begin{array}{c}\text { Baseline } \\
(1) \\
\end{array}$} & \multicolumn{5}{|c|}{ Panel A. Placebo crops I } \\
\hline & & $(2)$ & $(3)$ & $(4)$ & $(5)$ & $(6)$ \\
\hline $\begin{array}{l}\text { Crop used for instrument: } \\
\text { Mean production, 1971-2006 }\end{array}$ & $\begin{array}{l}\text { Wheat } \\
{[59,316]}\end{array}$ & $\begin{array}{l}\text { Oranges } \\
{[9,070]}\end{array}$ & $\begin{array}{l}\text { Grapes } \\
{[5,145]}\end{array}$ & $\begin{array}{l}\text { Lettuce } \\
{[3,432]}\end{array}$ & $\begin{array}{c}\text { Cotton lint } \\
{[3,350]}\end{array}$ & $\begin{array}{l}\text { Onions } \\
{[2,394]}\end{array}$ \\
\hline $\begin{array}{l}\text { Lag US production }(1,000 \mathrm{MT}) \times \\
\text { avg. prob. of any US food aid }\end{array}$ & $\begin{array}{c}0.00909 \\
(0.00322)\end{array}$ & $\begin{array}{c}-0.01977 \\
(0.01960)\end{array}$ & $\begin{array}{c}0.04829 \\
(0.03094)\end{array}$ & $\begin{array}{c}-0.07371 \\
(0.10535)\end{array}$ & $\begin{array}{c}-0.03456 \\
(0.04588)\end{array}$ & $\begin{array}{c}-0.09759 \\
(0.15061)\end{array}$ \\
\hline $\begin{array}{l}\text { Standardized beta coefficient } \\
R^{2}\end{array}$ & $\begin{array}{l}0.452 \\
0.525\end{array}$ & $\begin{array}{r}-0.154 \\
0.526\end{array}$ & $\begin{array}{l}0.212 \\
0.526\end{array}$ & $\begin{array}{r}-0.218 \\
0.526\end{array}$ & $\begin{array}{r}-0.101 \\
0.526\end{array}$ & $\begin{array}{r}-0.210 \\
0.526\end{array}$ \\
\hline \multirow[t]{3}{*}{ Observations } & 4,089 & 4,089 & 4,089 & 4,089 & 4,089 & 4,089 \\
\hline & & \multicolumn{5}{|c|}{ Panel B. Placebo crops II } \\
\hline & & $(7)$ & (8) & $(9)$ & $(10)$ & $(11)$ \\
\hline $\begin{array}{l}\text { Crop used for instrument: } \\
\text { Mean production, 1971-2006 }\end{array}$ & & $\begin{array}{c}\text { Grapefruit } \\
{[2,268]}\end{array}$ & $\begin{array}{c}\text { Cabbages } \\
{[1,596]}\end{array}$ & $\begin{array}{l}\text { Watermelons } \\
\quad[1,428]\end{array}$ & $\begin{array}{c}\text { Carrots and } \\
\text { turnips } \\
{[1,395]}\end{array}$ & $\begin{array}{c}\text { Peaches and } \\
\text { nectarines } \\
{[1,331]}\end{array}$ \\
\hline $\begin{array}{l}\text { Lag US production }(1,000 \mathrm{MT}) \times \\
\text { avg. prob. of any US food aid }\end{array}$ & & $\begin{array}{c}-0.00588 \\
(0.08511)\end{array}$ & $\begin{array}{l}-0.08000 \\
(0.07137)\end{array}$ & $\begin{array}{r}-0.34902 \\
(0.20577)\end{array}$ & $\begin{array}{r}-0.22736 \\
(0.13532)\end{array}$ & $\begin{array}{c}0.17813 \\
(0.17234)\end{array}$ \\
\hline $\begin{array}{l}\text { Standardized beta coefficient } \\
R^{2}\end{array}$ & & $\begin{array}{r}-0.011 \\
0.525\end{array}$ & $\begin{array}{r}-0.114 \\
0.526\end{array}$ & $\begin{array}{r}-0.430 \\
0.526\end{array}$ & $\begin{array}{r}-0.288 \\
0.526\end{array}$ & $\begin{array}{l}0.198 \\
0.526\end{array}$ \\
\hline Observations & & 4,089 & 4,089 & 4,089 & 4,089 & 4,089 \\
\hline
\end{tabular}

Notes: An observation is a country and a year. The sample includes 125 non-OECD countries for the years 1971-2006. All regressions include the full set of baseline controls (see Table 2 columns 5-7 for a full list). Coefficients are reported with standard errors clustered at the country level in parentheses. "Onions" are bulb onions and do not include shallots or green onions. **The point estimates and standard errors are multiplied by 1,000 for presentation purposes.

production of foods not shipped as food aid should not have the same relationship with conflict as US wheat production does.

Using total production (by weight) during our sample period, we examine the most widely grown crops in the United States. ${ }^{27}$ We then identify the ten most widely grown crops that are never shipped as food aid during our sample period. In order from the most to the least produced, these are: oranges, grapes, lettuce, cotton lint, onions, grapefruit, cabbages, watermelons, carrots/turnips, and peaches/nectarines.

The results of the placebo test are reported in Table 5. Column 1 reproduces the baseline reduced-form estimate from column 6 of Table 2 for comparison. The estimates in columns 2-11 show that the coefficients for the placebo crops are all close to zero. Unlike wheat, for no other crop do we estimate a positive and statistically significant relationship between the constructed instrument and conflict. ${ }^{28}$ Overall, the estimates provide confirmation of the validity of our estimation strategy.

The second test checks that our first-stage estimates are not confounded by spurious positive trends between US wheat production and food aid shipments to US food aid recipients. We estimate alternative first-stage equations where the instrument is used to predict past food aid rather than future food aid. As reported in online Appendix Table A4, we find no relationship between our instrument and past

\footnotetext{
${ }^{27}$ Production data are from FAO's ProdSTAT database.

${ }^{28}$ To compare the magnitudes of the coefficients, we also report standardized beta coefficients (since the production of different commodities occurs on very different scales).
} 
Table 6-The Effect of Food Aid on Civil Conflict: Robustness to Alternative Specifications

\begin{tabular}{|c|c|c|c|c|c|}
\hline $\begin{array}{l}\text { Dependent variable: } \\
\text { Incidence of civil conflict }\end{array}$ & $\begin{array}{c}\text { Baseline } \\
\text { specification } \\
\text { (1) }\end{array}$ & $\begin{array}{l}\text { Instrument: } \\
\text { Lagged US } \\
\text { wheat prod. } \times \\
\text { lagged 1-year } \\
\text { food aid prob. } \\
\quad(2)\end{array}$ & $\begin{array}{c}\text { Instrument: } \\
\text { Lagged US } \\
\text { wheat prod. } \times \\
\text { lagged 2-year } \\
\text { avg. food } \\
\text { aid prob. } \\
\text { (3) }\end{array}$ & $\begin{array}{c}\text { Instrument: } \\
\text { Lagged US } \\
\text { wheat prod. } \times \\
\text { lagged 4-year } \\
\text { avg. food } \\
\text { aid prob. } \\
\text { (4) }\end{array}$ & $\begin{array}{c}\text { Normalizing } \\
\text { US wheat aid } \\
\text { by population } \\
\text { (5) }\end{array}$ \\
\hline $\begin{array}{l}\text { Panel A. Alternative specificati } \\
\text { US wheat aid }(1,000 \mathrm{MT})\end{array}$ & $\begin{array}{l}\text { ns I } \\
\qquad \begin{array}{c}0.00254 \\
(0.00088)\end{array}\end{array}$ & $\begin{array}{c}0.00284 \\
(0.00164)\end{array}$ & $\begin{array}{c}0.00274 \\
(0.00149)\end{array}$ & $\begin{array}{c}0.00284 \\
(0.00159)\end{array}$ & $\begin{array}{c}0.0351 \\
(0.0145)\end{array}$ \\
\hline Standardized beta coefficient & 0.777 & 0.866 & 0.834 & 0.621 & 0.681 \\
\hline Kleibergen-Paap $F$-statistic & 12.10 & 7.11 & 8.88 & 1.80 & 17.61 \\
\hline Observations & 4,089 & 3,980 & 3,870 & 3,647 & 4,089 \\
\hline $\begin{array}{l}\text { Dependent variable: } \\
\text { Incidence of civil conflict }\end{array}$ & $\begin{array}{l}\text { Taking natural } \\
\text { logs of US } \\
\text { wheat aid and } \\
\text { production } \\
(6)\end{array}$ & $\begin{array}{l}\text { Dropping } \\
\text { former } \\
\text { Soviet Union } \\
\text { countries } \\
(7)\end{array}$ & $\begin{array}{c}\text { Dropping } \\
\text { years } \\
1971-1973 \\
(8)\end{array}$ & $\begin{array}{c}\text { Including } \\
\text { lagged US } \\
\text { wheat aid } \\
(9)\end{array}$ & $\begin{array}{l}\text { Including a } \\
\text { lead of US } \\
\text { wheat aid } \\
(10)\end{array}$ \\
\hline \multicolumn{6}{|c|}{ Panel B. Alternative specifications II } \\
\hline US wheat aid (1,000 MT) & $\begin{array}{l}0.165 \\
(0.0541)\end{array}$ & $\begin{array}{c}0.00266 \\
(0.00091)\end{array}$ & $\begin{array}{c}0.00272 \\
(0.00108)\end{array}$ & $\begin{array}{c}0.00439 \\
(0.00262)\end{array}$ & $\begin{array}{c}0.00368 \\
(0.00289)\end{array}$ \\
\hline US wheat aid (year $t-1)$ & & & & $\begin{array}{c}-0.00289 \\
(0.00335)\end{array}$ & \\
\hline US wheat aid (year $t+1)$ & & & & & $\begin{array}{c}-0.00112 \\
(0.00316)\end{array}$ \\
\hline Standardized beta coefficient & 0.760 & 0.828 & 0.837 & 1.342 & 1.140 \\
\hline Kleibergen-Paap $F$-statistic(s) & 21.92 & 11.41 & 13.80 & $7.61 ; 3.87$ & $7.46 ; 2.79$ \\
\hline Observations & 4,089 & 3,858 & 3,798 & 3,980 & 3,964 \\
\hline
\end{tabular}

Notes: 2SLS estimates are reported. The sample includes 125 non-OECD countries for the years 1971-2006. The regressions include the full set of baseline controls (see Table 2, columns 5-7 for a list). Coefficients are reported with standard errors clustered at the country level in parentheses. The table also reports standardized "beta coefficients" for US wheat aid.

US food aid. The relationship is statistically insignificant, negative, and very small in magnitude. These results support our identification assumptions.

\section{G. Additional Robustness Checks}

We now check the robustness of our 2SLS estimates. We first examine the sensitivity of the baseline estimates to the use of alternative specifications. Estimates are reported in Table 6 with the baseline estimate reported in column 1 for comparison. Columns 2-4 report estimates using alternatively constructed interaction instruments. Rather than interacting lagged US wheat production with a country's average propensity to receive food aid over the sample period, we instead interact lagged production with a country's propensity to receive food aid during the recent past, while controlling directly for this measure in the estimating equation. Estimates using an indicator variable for whether the country received food aid in period $t-1$ 
is reported in column 2. As shown, the estimates are very similar to the baseline estimates, although the standard errors are larger. Next, we consider measures over a longer time horizon and use the proportion of years from periods $t-1$ to $t-2$, and from periods $t-1$ to $t-4$ that a country received food aid from the United States to construct the instrument. ${ }^{29}$ One shortcoming of this approach is that our sample period is reduced by the time horizon we use in constructing the instrument-i.e., two years and four years. As reported in columns 3 and 4, using these alternative instruments, we continue to estimate positive effects of food aid on civil conflict. ${ }^{30}$

In columns 5 and 6 , we show that we obtain qualitatively identical results if we normalize US food aid shipments by the recipient's population or if we measure US food aid and US production in natural logs rather than raw values. In both cases, the results remain robust, and the magnitudes of the estimated effect of food aid, assessed by comparing standardized beta coefficients, are similar. Thus, our results are not specific to our choice of functional form.

We next check the robustness of our estimates to the use of alternative samples. Our baseline sample includes 14 countries that were formerly part of the Soviet Union and, therefore, do not enter the sample until 1991. In column 7, we show that we obtain nearly identical estimates if we exclude these countries from the sample.

The quality of the FAO food aid data is poorest in the early years of the sample. ${ }^{31}$ Hence, we check that our estimates are robust to the omission of the first three years of the sample, 1971-1973. The estimates for the smaller sample, which are reported in column 8, are nearly identical to the baseline estimates.

Finally, we include instrumented one-year leads and lags of US wheat aid. Columns 9 and 10 show that the contemporaneous measure of US wheat aid is similar in magnitude to the baseline estimate with these additional controls. The coefficients for the lead and lag variables are statistically insignificant, and smaller in magnitude than the contemporaneous effect. These results are most consistent with US food aid primarily affecting conflict during the year it is received. ${ }^{32}$ However, note that the estimates in columns 9 and 10 are imprecisely estimated due to collinearity between the lags, leads, and contemporaneous variables. As well, since the first-stages estimates are also fairly weak, they should be interpreted cautiously.

For completeness, we also consider the effect of wheat aid from other donors. Among the world's largest wheat donors, only two other countries-Canada and Japan - also have agricultural and food aid policies that are donor driven and centered around surplus disposal as in the United States. In online Appendix Table A5, we show that lagged production predicts aid shipments for Canada and Japan only. For the two countries, we find that the 2SLS estimates are similar in magnitude to

\footnotetext{
${ }^{29}$ Note that the recent-history-of-conflict indicator variables are time varying and therefore, not captured by country-fixed effects. Therefore, we flexibly control for the measure directly in the estimating equation (using a second-degree polynomial).

${ }^{30}$ Note that the first stage of the specification from column 4 is weak. As a result, the 90 percent Anderson-Rubin confidence intervals include zero. They are: $[-0.00241,0.00808]$.

${ }^{31}$ For example, in 1971, 150,500 MT of wheat aid from the United States is reported as being shipped to an unspecified recipient. The same figure is 134,800 in 1972 and 95,400 in 1973. The amount of unspecified wheat aid in 1974 is $10,000 \mathrm{MT}$, after which it is zero for all but three subsequent years.

${ }^{32}$ An alternative strategy that sidesteps the issue of collinearity, is to estimate separately the relationship between each measure of US aid and conflict. Online Appendix Table A7 shows that in this case, only the coefficients for wheat aid in period $t$ and wheat aid in period $t-1$ are positive and statistically significant.
} 
the estimate for the United States, although less precisely estimated. ${ }^{33}$ This is not surprising given that the magnitude of wheat aid shipments from Canada and Japan pales in comparison to the volumes shipped from the United States (see online Appendix Table A6).

\section{Mechanisms}

\section{A. Onset and Duration}

Our main outcome of interest, the incidence of civil conflict, reflects both the onset of new conflicts and the continuation of existing conflicts. Anecdotally, there are many accounts of food aid affecting both onset and duration. For example, it has been argued that humanitarian aid during the Nigeria-Biafra civil conflict (19671970) strengthened the rebel leader Odumegwu Ojukwu, causing the conflict to last 12 to 16 months longer than it otherwise would have (Polman 2010, pp. 114-122). More recently, observers have argued that the aid given to Hutu extremists in refugee camps allowed Hutu leaders to regroup, regain resources, and launch raids and attacks in Rwanda, leading to the First and Second Congo Wars (Polman 2010, pp. 13-34). To investigate the contributions of onset and duration to the changes in incidence, we separately estimate the effect of food aid on the two outcomes.

To examine the effect on onset, we start with specifications used in previous studies. We first examine onset using the methodology from Collier and Hoeffler (2004), which removes observations that are periods of continued conflict. That is, the sample only includes periods of no conflict and periods of conflict onset. The dependent variable equals one if period $t$ is the first period of a conflict episode. The analysis also includes our full set of baseline control variables. The 2SLS estimate of the effect of US food aid on the onset of civil conflict is reported in column 1 of Table 7. We find a positive, but statistically insignificant effect of US food aid on civil conflict onset.

Column 2 reports estimates using an alternative specification from Fearon and Laitin (2003). Rather than excluding periods of continued conflict from the sample, the authors include all observations and control for the incidence of civil conflict in the previous period. This captures the mechanical relationship between the onset of civil conflict and the presence of conflict in the previous period. This alternative estimation strategy generates a point estimate that is 40 percent lower than the estimate reported in column 1 and is also imprecisely estimated.

Next, we examine the effect of US food on the onset of conflict by estimating a hazard model. The event of interest is the onset of civil conflict. ${ }^{34}$ Let $t$ index time, $i$ index civil conflicts, and $T_{i} \geq 0$ denote the length, in years, of continued peace (i.e., the duration). The sample includes all country-years that are "at risk" for transition into conflict, i.e., all of the observations for which there was no civil conflict in the

\footnotetext{
${ }^{33}$ The 2 SLS estimate of the effect of donor wheat aid on civil conflict is 0.00283 for Canada and 0.00429 for Japan (compared to 0.00254 for the United States). The standard error is 0.00504 for Canada and 0.01019 for Japan.

${ }^{34}$ In this context, what one commonly refers to as "survival" in hazard models is continued peace.
} 
Table 7-The Effect of Food Aid on Civil Conflict Onset and Duration

\begin{tabular}{|c|c|c|c|c|c|c|c|c|}
\hline \multirow[b]{3}{*}{ Dependent variable: } & \multicolumn{2}{|c|}{ Civil war onset } & \multicolumn{3}{|c|}{ Civil war onset } & \multicolumn{3}{|c|}{ Civil war offset } \\
\hline & \multirow{2}{*}{$\begin{array}{c}\text { Collier and } \\
\text { Hoefler } \\
(2004) \\
(1) \\
\end{array}$} & \multirow{2}{*}{$\begin{array}{c}\text { Fearon } \\
\text { and Laitin } \\
(2003) \\
(2)\end{array}$} & \multicolumn{3}{|c|}{$\begin{array}{l}\text { Logistic discrete } \\
\text { time hazard model }\end{array}$} & \multicolumn{3}{|c|}{$\begin{array}{l}\text { Logistic discrete } \\
\text { time hazard model }\end{array}$} \\
\hline & & & (3) & (4) & (5) & (6) & (7) & (8) \\
\hline Mean of dependent variable & 0.041 & 0.034 & 0.063 & 0.063 & 0.063 & 0.185 & 0.185 & 0.185 \\
\hline $\begin{array}{l}\text { US wheat aid }(1,000 \mathrm{MT}) \\
\quad(\text { mean }=27.61)\end{array}$ & $\begin{array}{c}0.00102 \\
(0.00080)\end{array}$ & $\begin{array}{c}0.00061 \\
(0.00044)\end{array}$ & $\begin{array}{c}0.000064 \\
(0.000256)\end{array}$ & $\begin{array}{c}-0.000038 \\
(0.000241)\end{array}$ & $\begin{array}{c}-0.000012 \\
(0.000304)\end{array}$ & $\begin{array}{r}-0.000428 \\
(0.000249)\end{array}$ & $\begin{array}{r}-0.000507 \\
(0.000224)\end{array}$ & $\begin{array}{c}-0.000672 \\
(0.000345)\end{array}$ \\
\hline \multicolumn{9}{|l|}{ Controls: } \\
\hline $\begin{array}{l}\text { Lagged civil conflict } \\
\text { incidence }\end{array}$ & No & Yes & $\mathrm{N} / \mathrm{A}$ & N/A & $\mathrm{N} / \mathrm{A}$ & $\mathrm{N} / \mathrm{A}$ & $\mathrm{N} / \mathrm{A}$ & $\mathrm{N} / \mathrm{A}$ \\
\hline $\begin{array}{l}\text { Third-order poly } \\
\text { of duration }\end{array}$ & $\mathrm{N} / \mathrm{A}$ & $\mathrm{N} / \mathrm{A}$ & Yes & Yes & Yes & Yes & Yes & Yes \\
\hline $\begin{array}{l}\text { All time-invariant } \\
\text { controls }\end{array}$ & $\mathrm{N} / \mathrm{A}$ & $\mathrm{N} / \mathrm{A}$ & No & Yes & Yes & No & Yes & Yes \\
\hline Region-fixed effects & $\mathrm{N} / \mathrm{A}$ & $\mathrm{N} / \mathrm{A}$ & No & No & Yes & No & No & Yes \\
\hline First-stage $F$-statistic & 4.11 & 12.10 & 26.07 & 23.3 & 20.61 & 17.29 & 17.3 & 22.52 \\
\hline Observations & 3,377 & 4,089 & 1,454 & 1,454 & 1,454 & 709 & 709 & 709 \\
\hline
\end{tabular}

Notes: In all specifications, US wheat aid in year $t$ is instrumented by US wheat production in year $t-1 \times$ the probability of receiving any US food aid between 1971 and 2006. In columns 1 and 2, the dependent variable is an indicator that equals one for the onset of a civil war. Both specifications include the full set of baseline covariates. (See columns 5-7 of Table 2 for a list of these variables.) In column 1, observations that are periods of continued conflict are omitted from the sample. The regression in column 2 includes a one-year lag in the incidence of civil conflict as an additional control variable and uses the full sample. The $F$-statistic reported in columns 1 and 2 is the Kleibergen-Paap $F$-statistic. Columns 3-5 estimate a discrete time hazard model for the incidence of civil war onset. In this setting, survival is continued peace. Columns 6-8 estimate a discrete time hazard model for the incidence of civil war offset. In this setting, survival is continued conflict. The coefficients reported in columns 3-8 are marginal effects evaluated at means. The control function approach is used to generate IV estimates for the hazard models.

previous period. The estimation uses the discrete hazard $h_{i t}=\operatorname{Pr}\left(T_{i}=t \mid T_{i} \geq t\right)$, where it is assumed that $h_{i t}$ follows a logistic distribution. ${ }^{35}$

Estimates of the effect of US food aid on a country's transition into civil conflict are reported in columns 3-5 of Table 7. Column 3 reports estimates controlling for the duration of the conflict up until period $t-1$ only. We allow the effect of duration on the hazard rate to vary in a flexible manner by including a third degree polynomial of duration. In column 4 , we also control for the time-invariant country characteristics from our set of baseline control variables: a country's average real per capita GDP over the period, its average annual receipts of US military aid, its receipt of US economic aid (net of food aid), its average import of cereals, and its average production of cereals. Column 5 reports estimates from a specification that also controls for region fixed effects. Consistent with the estimates from columns 1 and 2, we do not find evidence that US food aid increases the onset of civil conflict. All three estimates are very close to zero and not statistically significant. Overall, the estimates from columns $1-5$ do not provide compelling evidence that food aid affects the onset of civil conflict.

The same hazard model can be used to estimate the effect of food aid on the probability of transitioning out of conflict and into peace. Examining civil conflict offset provides evidence of the effect of food aid on the duration of civil conflict.

\footnotetext{
${ }^{35}$ See, Allison (1984); Jenkins (1995); and Rivers and Vuong (1988) for further details.
} 
The estimates, which are reported in columns 6-8, provide strong evidence that US food aid decreases the probability of civil conflict offset, thus increasing the duration of existing conflicts. In all three specifications, the coefficients for US food aid are negative and highly significant.

Overall, the results reported in Table 7 suggest that food aid does not strongly affect the onset of civil conflicts, but that it does have a strong positive effect on the duration of civil conflicts.

\section{B. The Scale of Conflict}

Descriptive accounts of humanitarian aid tend to stress the role food aid plays in providing an important source of funds for small-scale rebel groups and "refugee warriors." This suggests that food aid may have larger effects on the incidence of small-scale conflicts. To investigate whether our results are driven by small-scale conflict, we disaggregate our main conflict measure, which includes both smalland large-scale conflicts, into small-scale conflicts with 25-999 battle deaths and large-scale conflicts with 1,000 or more battle deaths.

The estimates are reported in Table 8. Columns 1-3 report estimates of our baseline specification but with the incidence of any small-scale conflicts, small-scale intrastate conflicts, and small-scale interstate conflicts as dependent variables. Columns 4-7 report estimates with the incidence of any large-scale conflicts, large-scale intrastate conflicts, and large-scale interstate conflicts as dependent variables. For both smalland large-scale conflicts, we continue to find an effect of food aid on all conflicts and intrastate conflicts, but not on interstate conflicts. The estimated coefficients for small-scale conflicts are larger in magnitude and more precisely estimated than for large-scale conflicts. However, comparing the estimated coefficients relative to the means of the dependent variables, we find that the implied elasticity between conflict incidence and food aid is similar for small-scale and large-scale conflicts.

Overall, the results do not provide conclusive evidence on the relative importance of the effect of food aid on small-scale versus large-scale conflicts.

\section{Crowding-Out of Other Aid}

Although we interpret our estimates as showing that US food aid increases conflict in recipient countries, an alternative explanation is that food aid affects conflict indirectly by crowding out other types of aid. For example, other donor countries or multilateral agencies may respond to an increase in US food aid by reducing their own aid provisions. If these other forms of aid reduce conflict, then this form of "crowd-out" can explain why US food aid increases conflict. Similarly, if the reduction in aid is large enough, then an increase in US food aid could actually cause total foreign aid to decline, which can explain our results if total foreign aid reduces conflict. It is important to note that crowd-out does not undermine the causal interpretation of our estimates, but the mechanism of crowd-out is very different from the ones that motivate our study. More importantly, the two interpretations have very different policy implications.

We explore this possibility by reestimating equations (3) and (4) with other forms of aid provision as the second-stage dependent variable. We first examine the effect 
Table 8-The Effect of Food Aid on Small- and Large-Scale Conflicts

\begin{tabular}{lcccccccc}
\hline \hline & \multicolumn{2}{c}{ Small wars only: 25-999 battle deaths } & & \multicolumn{2}{l}{ Large wars only: 1000+ battle deaths } \\
\cline { 2 - 3 } $\begin{array}{l}\text { Dependent variable: } \\
\text { Incidence of conflict }\end{array}$ & $\begin{array}{c}\text { Any } \\
(1)\end{array}$ & $\begin{array}{c}\text { Intrastate } \\
(2)\end{array}$ & $\begin{array}{c}\text { Interstate } \\
(3)\end{array}$ & & $\begin{array}{c}\text { Any } \\
(4)\end{array}$ & $\begin{array}{c}\text { Intrastate } \\
(5)\end{array}$ & $\begin{array}{c}\text { Interstate } \\
(6)\end{array}$ \\
\hline Mean of dep. variable & 0.141 & 0.120 & 0.012 & & 0.076 & 0.056 & 0.014 \\
US wheat aid (1,000 MT) & 0.00170 & 0.00164 & -0.00006 & & 0.00129 & 0.00090 & -0.00038 \\
Kleibergen-Paap F-statistic & $(0.00090)$ & $(0.00087)$ & $(0.00015)$ & & $(0.00091)$ & $(0.00085)$ & $(0.00032)$ \\
Observations & 12.10 & 12.10 & 12.10 & & 12.10 & 12.10 & 12.10 \\
\hline
\end{tabular}

Notes: 2SLS estimates are reported. The sample includes 125 non-OECD countries for the years 1971-2006. US wheat aid in year $t$ is instrumented by US wheat production in year $t-1 \times$ the average probability of receiving any US food aid during 1971-2006. All regressions include the full set of baseline controls (see Table 2 columns 5-7 for a complete list). Coefficients are reported with standard errors clustered at the country level in parentheses.

TABle 9-The EfFect of Food Aid on Other Aid

\begin{tabular}{|c|c|c|c|c|c|c|c|c|}
\hline Dependent variable: & $\begin{array}{c}\text { World } \\
\text { wheat } \\
\text { aid } \\
(1,000 \mathrm{MT}) \\
(1)\end{array}$ & $\begin{array}{c}\text { World } \\
\text { cereal } \\
\text { aid } \\
(1,000 \mathrm{MT}) \\
(2)\end{array}$ & $\begin{array}{c}\text { Non-US } \\
\text { wheat } \\
\text { aid } \\
(1,000 \mathrm{MT}) \\
(3)\end{array}$ & $\begin{array}{c}\text { Non-US } \\
\text { cereal } \\
\text { aid } \\
(1,000 \mathrm{MT}) \\
(4)\end{array}$ & $\begin{array}{c}\text { US military } \\
\text { aid } \\
(1,000 \\
\text { real USD) } \\
(5)\end{array}$ & $\begin{array}{l}\text { US economic } \\
\text { aid excl. } \\
\text { food aid } \\
(1,000 \\
\text { real USD) } \\
(6)\end{array}$ & $\begin{array}{c}\text { Non-US net } \\
\text { ODA } \\
(1,000 \\
\text { real USD) } \\
(7)\end{array}$ & $\begin{array}{c}\text { Non-US net } \\
\text { ODA } 2 \\
(1000 \\
\text { real USD) } \\
(8)\end{array}$ \\
\hline Mean of dep. variable & 42.06 & 63.21 & 13.56 & 18.82 & 34,060 & 60,283 & 430,128 & 407,748 \\
\hline $\begin{array}{l}\text { US wheat aid }(1,000 \mathrm{MT}) \\
\quad(\text { mean }=27.61)\end{array}$ & $\begin{array}{c}1.226 \\
(0.122)\end{array}$ & $\begin{array}{c}1.211 \\
(0.281)\end{array}$ & $\begin{array}{c}0.233 \\
(0.120)\end{array}$ & $\begin{array}{c}0.133 \\
(0.172)\end{array}$ & $\begin{array}{l}1,073 \\
(448)\end{array}$ & $\begin{array}{c}776 \\
(591)\end{array}$ & $\begin{array}{c}1,923 \\
(1,210)\end{array}$ & $\begin{array}{l}1,443 \\
(863)\end{array}$ \\
\hline $\begin{array}{l}\text { Kleibergen-Paap } \\
F \text {-statistic }\end{array}$ & 12.10 & 12.10 & 12.10 & 12.10 & 12.10 & 12.10 & 12.10 & 12.10 \\
\hline Observations & 4,089 & 4,089 & 4,089 & 4,089 & 4,089 & 4,089 & 4,089 & 4,089 \\
\hline
\end{tabular}

Notes: 2SLS estimates are reported. The sample includes 125 non-OECD countries for the years 1971-2006. US wheat aid in year $t$ is instrumented by US wheat production in year $t-1 \times$ the probability of receiving any US food aid during 1971-2006. All regressions control for the full set of baseline controls (see Table 2 columns 5-7 for a full list). Coefficients are reported with standard errors clustered at the country level in parentheses.

of US wheat aid on total wheat aid provision (from all countries). If US wheat aid is crowding out wheat aid from other countries, then a one-unit (i.e., 1,000 MT) increase in US wheat aid will increase total food aid by less than 1,000 MT. Column 1 of Table 9 reports the point estimate, which is 1.23 and statistically significant. The point estimate, which is close to one, suggests that US aid does not crowd out the provision of wheat aid from other countries. Column 2 estimates the same regression but with cereal aid from all countries, rather than wheat aid as the dependent variable. The point estimate again shows that US wheat aid does not crowd out food aid from other countries. The lack of crowd-out for both wheat and cereal aid is confirmed by the estimates reported in columns 3 and 4, which show that US wheat aid has no effect on the provision of wheat aid and cereal aid from non-US donor countries. The point estimates are small, positive, and statistically insignificant.

We next turn to the possibility that US food aid crowds out the provision of other types of US aid, such as military aid or economic aid (net of food). Columns 5 and 6 show that US food aid does not crowd out these other types of aid. In fact, for military 
aid we find a small positive effect. This could reflect the fact that US soldiers and peacekeepers are sometimes used to help deliver US food aid and that these expenditures enter total US military aid figures. Columns 7 and 8 test whether US food aid crowds out total foreign aid provision by other countries. The columns report estimates of the effect of US food aid on two measures of total net Official Development Assistance (ODA) from non-US donors, both taken from Roodman's (2007) Net Aid Transfers Dataset. The measure of ODA used in column 7 includes loans and grants net of principal and interest payment on existing loans, while the measure used in column 8 is also net of cancelled "Other Official Finance" (OOF) loans, which are typically included as ODA. See Roodman (2007) for further details. We find no evidence of aid crowd-out using either measure. The coefficients in both specifications are small in magnitude, positive, and not statistically different from zero.

\section{Crowding-Out of Domestic Production}

A potential mechanism through which food aid may affect conflict is by crowding out domestic production, lowering the potential incomes of farmers, causing them to move into conflict-related activities. Here we examine this mechanism by testing whether US food aid receipts affect local crop prices and whether it affects local production. The production estimates, reported in columns 1 and 2 of Table 10, show that US food aid has no effect on recipient wheat production or recipient cereal production. The estimated effects are negative, but small in magnitude and statistically insignificant. This finding is consistent with the existing empirical evidence, which generally fails to find a link between food aid and production (Abdulai, Barrett, and Hoddinott 2005; FAO 2006, pp. 40-41). Columns 3 and 4 present estimates of the effect of US food aid on domestic wheat prices. Column 3 reports estimates for winsorized price data and column 4 reports estimates for log prices. ${ }^{36}$ As shown, we find no significant effect of US wheat aid on domestic prices. However, these findings should be interpreted with caution since the limited availability of the price data causes the sample size to be very small.

\section{Heterogeneous Effects of Food Aid}

The final part of our empirical analysis examines whether the effects of food aid are heterogeneous across different contexts, the results of which can help guide policy discussions and future studies on food aid. To explore potential heterogeneous effects, we allow the effect of US food aid on conflict to differ depending on particular characteristics of countries, measured by $I_{i r}$. In some cases, the characteristics also vary over time e.g., $I_{i r t}$.

Allowing for heterogeneity, the second-stage equation becomes

$$
C_{i r t}=\beta_{1} F_{i r t}+\beta_{2}\left(F_{i r t} \times I_{i r}\right)+\mathbf{X}_{i r t} \Gamma+\varphi_{r t}+\delta_{i r}+\varepsilon_{i r t},
$$

\footnotetext{
${ }^{36}$ Due to a small number of very extreme prices, examining the raw price data is essentially meaningless. The extreme prices appear to be due to periods of hyperinflation combined with the imprecision of using annual exchange rate and CPI data to construct the price series. For this reason, we undertake two strategies: winsorizing the data at $\$ 1,000$ per MT or taking the natural log of prices to reduce the influence of extreme values. Winsorizing at other reasonable values produces qualitatively identical results to those reported here.
} 
Table 10-The Effect of Food Aid on Recipient Country Cereal Production

\begin{tabular}{lcccc}
\hline \hline & $\begin{array}{c}\text { Recipient wheat } \\
\text { production } \\
(1,000 \mathrm{MT}) \\
(1)\end{array}$ & $\begin{array}{c}\text { Recipient cereals } \\
\text { production } \\
(1,000 \mathrm{MT})\end{array}$ & $\begin{array}{c}\text { Recipient wheat } \\
\text { price } \\
(\text { Windsorized) } \\
\text { Dependent variable: }\end{array}$ & $\begin{array}{c}\text { Recipient wheat } \\
\text { price } \\
\text { (natural log) }\end{array}$ \\
\hline Mean of dep. variable & $4,178.6$ & $10,162.5$ & 527.3 & 7.77 \\
US wheat aid (1,000 MT) & -7.206 & -7.177 & -0.329 & -0.00094 \\
$\quad($ mean = 27.61) & $(5.735)$ & $(9.721)$ & $(0.446)$ & $(0.00386)$ \\
Kleibergen-Paap F-statistic & 8.99 & 13.23 & 7.14 & 7.14 \\
Observations & 2,368 & 3,736 & 1,737 & 1,737 \\
\hline
\end{tabular}

Notes: 2SLS estimates are reported. The sample includes a maximum 125 non-OECD countries for the years 1971-2006. Due to missing production and price data, the samples are smaller than 4,089 observations. US wheat aid in year $t$ is instrumented by US wheat production in year $t-1 \times$ the probability of receiving any US food aid during 1971-2006. All regressions control for the full set of baseline controls (see Table 2 columns 5-7 for a full list). Coefficients are reported with standard errors clustered at the country level in parentheses.

where all other variables have the same definitions as in equation (3). Since the direct effect of the indicator variable $I_{i r}$ is absorbed by the country fixed effects, the only difference between equations (3) and (5) is the addition of the interaction term $F_{i r t} \times I_{i r}$ in equation $(5)$.

To establish causality, we instrument for $F_{i r t}$ and $F_{i r t} \times I_{i r t}$ with $P_{t-1} \times \bar{D}_{i r}$, $P_{t-1} \times \bar{D}_{i r} \times I_{i r}$, and $P_{t-1} \times I_{i r}$. Thus the first-stage equation for $F_{i r t}$ is

$$
\begin{aligned}
F_{i r t}= & \pi_{1}\left(P_{t-1} \times \bar{D}_{i r} \times I_{i r}\right)+\pi_{2}\left(P_{t-1} \times \bar{D}_{i r}\right)+\pi_{3}\left(P_{t-1} \times I_{i r}\right) \\
& +\mathbf{X}_{i r t} \Gamma+\varphi_{r t}+\delta_{i r}+\varepsilon_{i r t} .
\end{aligned}
$$

The other first-stage equation, which is for the interaction term $F_{i r t} \times I_{i r}$, is identical to equation (6), but with $F_{i r t} \times I_{i r}$ as the dependent variable. In addition to the baseline set of covariates, $\mathbf{X}_{i r t}$ also includes the components of the triple interaction (double interactions and direct effects) that are not absorbed by fixed effects (e.g., $\bar{D}_{i r} \times I_{i r}$ and $I_{i r}$ are absorbed by the country fixed effects). ${ }^{37}$

We begin our analysis by examining whether the effects of food aid are more adverse in contexts that are prone to conflict. To do this, we use a straightforward proxy for a country's propensity for peace: an indicator variable that equals one if there was no conflict in the last five, ten, fifteen, or twenty years in country $i$. This measure varies over time and enters into equations (5) and (6) as $I_{i r t}$.

The estimates are reported in Table 11, where the baseline estimates are reproduced in column 1 for comparison. The first row of columns 2-5 reports the coefficient for $F_{i r t}$, which is the effect of food aid for countries that experienced no conflict in the recent past. All estimates are positive and statistically significant. The next row reports the coefficient for the interaction term, $F_{i r t} \times I_{i r t}$, which captures the differential effect of food aid between countries that experienced no recent conflict

\footnotetext{
${ }^{37}$ When the heterogeneity characteristic does not vary over time, $I_{i r}$ does not include any additional controls. However, when the characteristic varies over time, then $I_{i r t}$ and $\bar{D}_{i r} \times I_{i r t}$ is also included in $\mathbf{X}_{i r t}$ since they are not captured by the country fixed effects (as is the case when the interaction term is $I_{i r}$ ).
} 
Table 11-Heterogeneous Effects of Food Aid on Civil Conflict: Conflict Prior to Food Aid

\begin{tabular}{lccccc}
\hline \hline $\begin{array}{l}\text { Dependent } \\
\text { variable: Incidence } \\
\text { of civil conflict }\end{array}$ & $(1)$ & $\begin{array}{c}\text { 20 year } \\
\text { window } \\
(2)\end{array}$ & $\begin{array}{c}15 \text { year } \\
\text { window } \\
(3)\end{array}$ & $\begin{array}{c}10 \text { year } \\
\text { window } \\
(4)\end{array}$ & $\begin{array}{c}5 \text { year } \\
\text { window } \\
(5)\end{array}$ \\
\hline US wheat aid (1,000 MT) & 0.00252 & 0.00320 & 0.00376 & 0.00381 & 0.00446 \\
& $(0.00089)$ & $(0.00128)$ & $(0.00132)$ & $(0.00149)$ & $(0.00262)$ \\
US wheat aid $\times$ no past conflict & & -0.00579 & -0.00782 & -0.00735 & -0.00607 \\
& & $(0.00353)$ & $(0.00517)$ & $(0.00462)$ & $(0.00369)$ \\
US wheat aid + (US wheat aid & & -0.00259 & -0.00406 & -0.00355 & -0.00160 \\
$\quad \times$ no past conflict) & \multirow{2}{*}{$\begin{array}{c}(0.00300) \\
\text { Kleibergen-Paap F-statistic(s) }\end{array}$} & $5.30 ; 0.45$ & $4.15 ; 0.36$ & $3.34 ; 0.46$ & $2.15 ; 1.62$ \\
Observations & 4,071 & 4,071 & 4,071 & 4,071 & 4,071 \\
\hline
\end{tabular}

Notes: 2SLS estimates are reported. The baseline sample in column 1 includes 125 non-OECD countries for the years 1971-2006. The sample size in columns 2-5 is slightly smaller due to the availability of past conflict data. US wheat aid in year $t$ and the interaction of wheat aid and the indicator variable are instrumented with US wheat production in year $t-1 \times$ the probability of receiving any US food aid during 1971-2006, and the triple interaction of the indicator $\times$ US wheat production in year $t-1 \times$ the probability of receiving any US food aid during 1971-2006. The regressions also include the relevant double interaction terms. All regressions control for the full set of baseline controls (see Table 2 columns 5-7 for the full list). Coefficients are reported with standard errors clustered at the country level in parentheses. The joint estimate for US wheat aid + US wheat aid $\times$ no past conflict indicator are reported at the bottom of of the table. Kleibergen-Paap $F$-statistics are reported. When multiple $F$-statistics are reported, the first $F$-statistic is from the first-stage regression with US wheat aid as the dependent variable and the second from the first-stage with US wheat aid $\times$ indicator variable as the dependent variable.

and countries that experienced some conflict recently. In all four specifications, the estimates for the interaction term are negative and significant, indicating that food aid has less adverse effects on conflict in countries that have recently been peaceful.

The sum of the coefficients for $F_{i r t}$ and $F_{i r t} \times I_{i r t}$, as well as the standard errors, are reported at the bottom of the table. This reflects the total effect of food aid for countries that have not experienced conflict in the recent past. The combined effects are all indistinguishable from zero, suggesting that food aid does not increase conflict in countries that have been peaceful in recent years. ${ }^{38}$ Therefore, our baseline estimates appear to be driven solely by countries with a recent history of conflict. ${ }^{39}$

In light of this finding, we consider the influences of factors that may contribute to recent conflict. We focus on factors that emerge most frequently in the literature: income, political institutions, ethnic diversity, and natural resource dependence (Blattman and Miguel 2010). Most of these covariates of interest either vary little over time or are not available for every year of the sample. We therefore examine time-invariant country-level measures by constructing an indicator variable $I_{i r}$ that equals one if the country characteristic (averaged over all time periods, when relevant) is greater than the median among countries in the sample. It is this measure of $I_{i r}$ that is used in equations (5) and (6).

The results are reported in Table 12, where column 1 reproduces the baseline estimates for comparison. We begin by allowing for heterogeneity by average income,

\footnotetext{
${ }^{38}$ In fact, the combined effect in all four specifications is negative and sizeable, but because of large standard errors, they are insignificant. It is possible that food aid even reduces conflict for countries without a history of conflict. However, due to imprecision our estimates do not show this.

${ }^{39}$ An important shortcoming of the heterogeneity estimates of Table 11 is that the first stages are weak. This generates the possibility of large biases in the IV estimates and standard errors that are downward biased. This important caveat should be kept in mind when evaluating the estimates.
} 
Table 12-Heterogeneous Effects of Food Aid on Civil Conflict: Potential Contributors to Civil Conflict

\begin{tabular}{|c|c|c|c|c|c|c|c|}
\hline $\begin{array}{l}\text { Dependent variable: } \\
\text { Incidence of civil conflict }\end{array}$ & (1) & (2) & (3) & (4) & (5) & (6) & (7) \\
\hline US wheat aid (1,000 MT) & $\begin{array}{c}0.00254 \\
(0.00088)\end{array}$ & $\begin{array}{c}0.00155 \\
(0.00083)\end{array}$ & $\begin{array}{c}0.00270 \\
(0.00102)\end{array}$ & $\begin{array}{c}0.00222 \\
(0.00130)\end{array}$ & $\begin{array}{c}0.00516 \\
(0.00229)\end{array}$ & $\begin{array}{c}0.00770 \\
(0.00601)\end{array}$ & $\begin{array}{c}0.00500 \\
(0.00401)\end{array}$ \\
\hline $\begin{array}{l}\text { US wheat aid } \times \text { indicator for: } \\
\text { High income }\end{array}$ & & $\begin{array}{c}0.00305 \\
(0.00282)\end{array}$ & & & & & \\
\hline High resource dependence & & & $\begin{array}{r}-0.00030 \\
(0.00207)\end{array}$ & & & & \\
\hline High polity (democratic) & & & & $\begin{array}{c}0.00043 \\
(0.00248)\end{array}$ & & & \\
\hline Low ethnic polarization & & & & & $\begin{array}{c}-0.00469 \\
(0.00256)\end{array}$ & & $\begin{array}{c}-0.00708 \\
(0.00719)\end{array}$ \\
\hline Low ethnic diversity & & & & & & $\begin{array}{c}-0.00743 \\
(0.00727)\end{array}$ & $\begin{array}{c}0.00261 \\
(0.01012)\end{array}$ \\
\hline $\begin{array}{l}\text { US wheat aid }+ \text { (US wheat } \\
\text { aid } \times \text { indicator) }\end{array}$ & & $\begin{array}{c}0.00460 \\
(0.00256)\end{array}$ & $\begin{array}{c}0.00240 \\
(0.00169)\end{array}$ & $\begin{array}{c}0.00266 \\
(0.00174)\end{array}$ & $\begin{array}{c}0.00047 \\
(0.00083)\end{array}$ & $\begin{array}{c}0.00027 \\
(0.00145)\end{array}$ & $\begin{array}{c}0.00052 \\
(0.00099)\end{array}$ \\
\hline Kleibergen-Paap $F$-statistic(s) & 12.10 & $3.21 ; 5.30$ & $3.50 ; 1.56$ & $2.23 ; 3.00$ & $4.11 ; 1.47$ & $0.64 ; 1.07$ & $0.86 ; 0.23 ; 0.45$ \\
\hline Observations & 4,089 & 4,089 & 4,089 & 3,942 & 3,635 & 4,048 & 3,594 \\
\hline
\end{tabular}

Notes: 2SLS estimates are reported. The baseline sample in column 1 includes 125 non-OECD countries for the years 1971-2006. The sample size in columns 2-7 varies according to data availability. US wheat aid in year $t$ and the interaction of wheat aid and the indicator variable are instrumented with US wheat production in year $t-1 \times$ the probability of receiving any US food aid during 1971-2006, and the triple interaction of the indicator $\times$ US wheat production in year $t-1 \times$ the probability of receiving any US food aid during 1971-2006. The regressions also include the relevant double interaction terms. All regressions control for the full set of baseline controls (see Table 2 columns 5-7 for the full list). Coefficients are reported with standard errors clustered at the country level in parentheses. The joint estimates for US wheat aid + US wheat aid $\times$ indicator variable (and the standard error) are reported at the bottom of the table. Kleibergen-Paap $F$-statistics are also reported. When multiple $F$-statistics are reported, the first $F$-statistic is from the first-stage regression with US wheat aid as the dependent variable and the second from the first-stage with US wheat aid $\times$ indicator variable as the dependent variable.

measured by real per capita GDP taken from the Penn World Tables. Given the link between income and conflict, a natural hypothesis is that food aid will have smaller effects on civil conflict in higher income countries. The estimates, reported in column 2 , show that this is not the case. The coefficient for the interaction term is positive and statistically insignificant.

Column 3 examines whether being well endowed with natural resources can influence the relationship between food aid and conflict. We measure resource abundance with the share of resource rents in GDP, which is taken from the World Development Indicators. The influence is a priori ambiguous. On the one hand, resource-rich countries are often observed to be prone to conflict and therefore this may strengthen the link between food aid and conflict. On the other hand, resource endowments may reduce the importance of food aid for fighting factions, and thus weaken the link between food aid and conflict. The estimates show that the link between food aid and conflict is weaker in more resource rich countries, which is consistent with the latter hypothesis. However, the differential effect is imprecisely estimated.

A lack of democratic accountability has been associated with more civil conflict. In addition, Besley and Persson (2011) show theoretically and empirically that lack of accountability can magnify the effect of aid on conflict. We therefore examine the differential effect of food aid on conflict among more democratic regimes, measured using the Polity2 variable from the PolityIV database. As reported in column 4, we 
do not find evidence that the effect of aid on conflict is weaker for democracies. We find a differential effect that is very close to zero and statistically insignificant.

Finally, we investigate the influence of ethnicity, measured by ethnic diversity and ethnic polarization, which have been found to reduce within-country cohesion and to be associated with more civil conflict. ${ }^{40}$ Columns 5 and 6 show that food aid has a weaker effect on the incidence of civil conflict in countries with low ethnic fractionalization and low polarization, although the interaction term for low ethnic fractionalization is not significant at standard levels. Since ethnic diversity and polarization are mechanically correlated (especially at low levels of fractionalization), we include both interaction terms in column 7 . We find that only the low-polarization interaction remains negative, although it is no longer statistically significant.

The second set of heterogeneous effects that we examine attempts to provide additional insights into specific mechanisms underlying the relationship between food aid and conflict. We first consider the role of domestic food production. We examine two types of heterogeneity. The first is whether the effects of food aid on conflict differ depending on the extent to which the country has specialized in the production of cereal crops. A priori, the direction of this effect is unclear. Food aid may be more valuable when there is less local production and therefore have a weaker effect in countries with more domestic cereal production. However, food aid may have a larger adverse effect on local incomes when there is more cereal production and therefore the effect of food aid on conflict may be greater in countries with more cereal production. The estimates, reported in column 2 of Table 13, is the net of all potentially opposing forces. The sign of the coefficient for the interaction term suggests that food aid causes more conflict in low cereal producing countries, although the coefficient is imprecisely estimated.

We also examine heterogeneity based on variation in cereal production over time. Specifically, for each country, we construct an indicator variable that equals one in years when a country's production is lower than its historical average (1971-2006). We test whether the effects of food aid are greater in years of low cereal production. It is possible that food aid has greater value, and therefore has greater effects, in years when food is more scarce. The estimates, reported in column 3 , do not provide support for the hypothesis. The coefficient on the interaction term is negative and statistically insignificant.

Next, we consider the importance of road networks in recipient countries. This is motivated by first-hand accounts of armed factions stealing aid during transit, often by setting up road blocks. It follows that, all else equal, road blocks may be more effective where transportation networks are less developed since aid deliveries cannot easily circumvent them in the absence of alternative routes. We test this hypothesis by examining the influence of the annual average of kilometers of roads per capita during the sample period. The estimates reported in column 4 show that food aid has a slightly smaller effect, though statistically insignificant, on conflict in countries with better-developed road networks.

\footnotetext{
${ }^{40}$ The measure of ethnic diversity is from Alesina et al. (2003) and the measure of polarization is from the Ethnic Power Relations (EPR) Dataset. An alternative source for ethnic polarization is Montalvo and Reynal-Querol (2005). We choose to use the EPR because of its broader coverage of countries (155 versus 137). The results are qualitatively similar if we use the Montalvo and Reynal-Querol (2005) data.
} 
Table 13-Heterogeneous Effects of Food Aid on Civil Conflict: Potential Contributors to FoOd Aid Misappropriation

\begin{tabular}{lcccccc}
\hline \hline $\begin{array}{l}\text { Dependent variable: } \\
\text { Incidence of civil conflict }\end{array}$ & $(1)$ & $(2)$ & $(3)$ & $(4)$ & $(5)$ & $(6)$ \\
\hline US wheat aid (1,000 MT) & 0.00254 & 0.00186 & 0.00292 & 0.00248 & 0.00353 & 0.00266 \\
& $(0.00088)$ & $(0.00099)$ & $(0.00089)$ & $(0.00120)$ & $(0.00132)$ & $(0.00122)$ \\
& & & & & & \\
US wheat aid $\times$ indicator for: \\
Low cereal producer
\end{tabular}

Notes: 2SLS estimates are reported. The baseline sample in column 1 includes 125 non-OECD countries for the years 1971-2006. The sample size in columns 2-7 varies according to data availability. US wheat aid in year $t$ and the interaction of wheat aid and the indicator variable are instrumented with US wheat production in year $t-1 \times$ the probability of receiving any US food aid during 1971-2006, and the triple interaction of the indicator $\times$ US wheat production in year $t-1 \times$ the probability of receiving any US food aid during 1971-2006. The regressions also include the relevant double interaction terms. All regressions control for the full set of baseline controls (see Table 2 columns 5-7 for the full list). Coefficients are reported with standard errors clustered at the country level in parentheses. The joint estimates for US wheat aid + US wheat aid $\times$ indicator variable (and the standard error) are reported in the final row of the table. Kleibergen-Paap $F$-statistics are reported. When multiple $F$-statistics are reported, the first $F$-statistic is from the first-stage regression with US wheat aid as the dependent variable and the second from the first-stage with US wheat aid $\times$ indicator variable as the dependent variable.

Given the dramatic shift in foreign policy that occurred when the Cold War ended, we also examine the differential effects of food aid for the Cold War and post-Cold War era. Specifically, we investigate whether the shift in US aid policies that occurred with the end of the Cold War (e.g., Meernik, Krueger, and Poe 1998) influenced the link between food aid and conflict. Column 5 shows that the interaction of food aid and a Cold War indicator variable is negative, moderate in magnitude, but statistically insignificant.

The last dimension we examine is the political alliance between the recipient country and the United States. This could affect the links between food aid and conflict if, for example, the United States makes a greater effort to protect the food aid from rebel factions if the aid is being shipped to a political ally. We measure alliance using the fraction of a country's votes in the UN General Assembly that are aligned with the United States. ${ }^{41}$ Column 6 shows that the differential effect for US allies is negative, moderate in size, and statistically insignificant.

Finding that the positive link between food aid and conflict is isolated to countries that have experienced conflict in the recent past is consistent with the earlier result

\footnotetext{
${ }^{41}$ The data are taken from Gartzke (2006). They have been used previously in a number of papers to measure political alignment with the United States. See, for example, Qian and Yanagizawa (2009, 2010).
} 
that food aid increases the duration of conflicts. Other than the finding that ethnic polarization exacerbates the link between food aid and conflict, we do not find any other evidence of heterogeneous effects. Part of this may be due to the coarseness of the data used in our macro-level analysis. It may also be due to the weakness of the instruments in the first stage. ${ }^{42}$ Thus, the heterogeneity estimates should be interpreted with these shortcomings in mind.

\section{Conclusion}

Humanitarian aid is an important international policy tool for providing relief for populations that face endemic poverty. However, recent critics observe that humanitarian aid, and food aid in particular, may actually promote conflict. This controversial topic has sparked much debate among aid watchers. However, without more systematic evidence, it is difficult to begin to redesign policy. Our study takes a first-cut at this and aims to facilitate the discussion by providing novel rigorous causal evidence of the average effect of US wheat aid on conflict in recipient countries.

Our findings show that the concerns of critics are very real and that US food aid indeed promotes civil conflict on average. An increase in US food aid increases the incidence of armed civil conflict in recipient countries. US food aid does not crowd out other forms of aid or aid from other donors. Thus, the increase in conflict is really due to an increase in aid.

The effects we find are due to aid prolonging existing conflicts. We do not find evidence that aid precipitates the onset of new conflicts. Consistent with this, we also find that the adverse effects of food aid are concentrated among countries with a recent history of civil conflict.

At face value, our results portray a pessimistic view of food aid policies that could perhaps be extended to humanitarian aid more generally. However, such a peremptory interpretation is potentially misleading for several reasons. First, the fact that food aid has no effect on conflict in countries without a recent history of civil conflict isolates the problematic consequences we detect to a well-defined and observable subset of food aid recipients. Second, the fact that the 2SLS estimates of "randomly" allocated aid are larger than the OLS estimates of endogenously allocated aid is potentially encouraging. As discussed, although a downward bias of OLS estimates can arise for many reasons, one of these reasons is the selective distribution of aid. Thus, it is possible that part of the difference between the OLS and IV estimates transpires because, intentionally or not, aid has been directed to countries where it has less adverse effects. Finally, we emphasize that this study focuses on one of many potential consequences of food aid. For policy makers, our results should not be interpreted in isolation, but should be taken as one effect among many. For example, our results do not contradict the evidence for the many benefits of emergency humanitarian aid. Similarly, other types of aid such as technical assistance or cash

\footnotetext{
${ }^{42}$ An alternative explanation is that our reported estimates examine incidence, while US food aid affects the duration of conflict only. However, when we estimate our duration model allowing for the differential affects from Tables 12 and 13 we obtain similar results. These estimates are reported in online Appendix Tables A8 and A9.
} 
transfers could have very different effects from the delivery of food, which is easily stolen by armed groups.

The results of this study suggest several important avenues for future research. The first is to carefully document the different sources of endogeneity that may be attenuating the OLS estimates and evaluate the possibility that each source is helping to mitigate the harmful effects of food aid on conflict. The second is to examine other potential outcomes that are potentially affected by food aid. Such a comprehensive evaluation is necessary to fully assess the trade-offs of food aid policy. ${ }^{43}$ Finally, we need to better understand the mechanisms that underlie the relationship between food aid and conflict. We have attempted to do this to the extent possible given the available data and our macro-level analysis. Collecting and analyzing finer-grained, micro-level data would be extremely helpful for future research. ${ }^{44}$

In conclusion, our study takes only a small first step toward the larger goal of understanding the costs and benefits of food aid and humanitarian aid policies. Much more research is needed on the topic.

\section{REFERENCES}

Abdulai, Awudu, Christopher B. Barrett, and John Hoddinott. 2005. "Does Food Aid Really Have Disincentive Effects? New Evidence from Sub-Saharan Africa.” World Development 33 (10): 1689_ 1704.

Ahmed, Faisal. 2010. "The Repression Effect.” Unpublished.

Alesina, Alberto, Arnaud Devleeschauwer, William Easterly, Sergio Kurlat, and Romain Wacziarg. 2003. "Fractionalization." Journal of Economic Growth 8 (2): 155-94.

-Alesina, Alberto, and David Dollar. 2000. "Who Gives Foreign Aid to Whom and Why?" Journal of Economic Growth 5 (1): 33-63.

Allison, Paul D. 1984. Event History Analysis: Regression for Longitudinal Event Data. London: Sage Publications.

Anderson, Mary B. 1999. Do No Harm: How Aid Can Support Peace-or War. Boulder, CO: Lynne Rienner Publishers.

Ball, Richard, and Christopher Johnson. 1996. "Political, Economic, and Humanitarian Motivations for PL 480 Food Aid: Evidence from Africa.” Economic Development and Cultural Change 44 (3): 515-37.

Barnett, Michael. 2011. Empire of Humanity: A History of Humanitarianism. Ithaca: Cornell University Press.

Barrett, Christopher B., and Daniel G. Maxwell. 2005. Food Aid After Fifty Years: Recasting Its Role. London: Routledge.

-Bauer, Peter T. 1975. "N. H. Stern on Substance and Method in Development Economics." Journal of Development Economics 2 (4): 387-405.

Beck, Nathaniel, and Jonathan N. Katz. 2004. "Time-Series Cross-Section Issues: Dynamics, 2004." Unpublished.

-Besley, Timothy, and Torsten Persson. 2011. "The Logic of Political Violence." Quarterly Journal of Economics 126 (3): 1411-45.

-Blattman, Christopher, and Edward Miguel. 2010. “Civil War.” Journal of Economic Literature 48 (1): 3-57.

Boone, Peter. 1996. "Politics and the Effectiveness of Foreign Aid." European Economic Review 40 (2): 289-329.

\footnotetext{
${ }^{43}$ One set of outcomes include those related to health, such as infant mortality. Unfortunately, since existing country-level health data are often interpolated between survey years and vary little over short periods of time, our empirical strategy, which exploits year-to-year variation in aid, cannot easily be applied to study this outcome. See an earlier version of this paper, Nunn and Qian (2012), for a detailed discussion.

${ }^{44}$ Two examples of recent studies taking a more micro-oriented approach, although examining military and economic aid, are Dube and Naidu (2010) and Crost, Felter, and Johnston (2012).
} 
Bruckner, Markus, and Antonio Ciccone. 2010. "International Commodity Prices, Growth and the Outbreak of Civil War in Sub-Saharan Africa." Economic Journal 120 (544): 519-34.

-Burnside, Craig, and David Dollar. 2000. "Aid, Policies, and Growth.” American Economic Review 90 (4): 847-68.

Collier, Paul, and Anke Hoeffler. 2002. "Aid, Policy and Peace: Reducing the Risk of Civil Conflict." Defence and Peace Economics 13 (6): 435-50.

-Collier, Paul, and Anke Hoeffler. 2004. "Greed and Grievance in Civil War." Oxford Economic Papers 56 (4): 563-95.

Crost, Benjamin, Joseph Felter, and Patrick B. Johnston. 2012. "Aid Under Fire: Development Projects and Civil Conflict." Unpublished.

Dell, Melissa, Benjamin F. Jones, and Benjamin A. Olken. 2008. "Climate Shocks and Economic Growth: Evidence from the Last Half Century." National Bureau of Economic Research Working Paper 14132.

de Ree, Joppe, and Eleonora Nillesen. 2009. "Aiding Violence or Peace? The Impact of Foreign Aid on the Risk of Civil Conflict in Sub-Saharan Africa." Journal of Development Economics 88 (2): 301-13.

de Waal, Alex. 1997. Famine Crimes: Politics \& The Disaster Relief Industry in Africa. Bloomington, IN: Indiana University Press.

Dube, Oeindrila, and Suresh Naidu. 2010. "Bases, Bullets, and Ballots: The Effect of U.S. Military Aid on Political Conflict in Colombia." Center for Global Development Working Paper 197.

Dube, Oeindrila, and Juan F. Vargas. 2013. "Commodity Price Shocks and Civil Conflict: Evidence from Colombia." Review of Economic Studies 80(4): 1384-1421.

-Easterly, William. 2003. “Can Foreign Aid Buy Growth?” Journal of Economic Perspectives 17 (3): 23-48.

-Easterly, William, Ross Levine, and David Roodman. 2004. "Aid, Policies, and Growth: Comment." American Economic Review 94 (3): 774-80.

FAO. 2006. "The State of Food and Agriculture: Food Aid for Food Security?" FAO Agricultural Series No. 37.

FAO. 2008. "FAOSTAT Database.” http://faostat.fao.org (accessed August 2008).

-Fearon, James D., and David D. Laitin. 2003. "Ethnicity, Insurgency, and Civil War." American Political Science Review 97 (1): 75-90.

Gartzke, Erik. 2006. “The Affinity of Nations Index, 1946-2002.” Unpublished.

Imbens, Guido W., and Joshua D. Angrist. 1994. "Identification and Estimation of Local Average Treatment Effects.” Econometrica 62 (2): 467-75.

-Jenkins, Stephen P. 1995. "Easy Estimation Methods for Discrete-Time Duration Models." Oxford Bulletin of Economics and Statistics 57 (1): 129-38.

-Judson, Ruth A., and Ann L. Owen. 1999. "Estimating Dynamic Panel Data Models: A Guide for Macroeconomists.” Economics Letters 65 (1): 9-15.

Kahn, Clea, and Elena Lucchi. 2009. "Are Humanitarians Fuelling Conflicts? Evidence from Eastern Chad and Darfur." Humanitarian Exchange Magazine 43: 20-23.

-Kirwan, Barrett E., and Margaret McMillan. 2007. "Food Aid and Poverty." American Journal of Agricultural Economics 89 (5): 1152-60.

Kuziemko, Ilyana, and EricWerker. 2006. "How Much is a Seat on the Security Council Worth? Foreign Aid and Bribery at the United Nations.” Journal of Political Economy 114 (5): 905-30.

Lavy, Victor. 1992. "Alleviating Transitory Food Crises in Sub-Saharan Africa: International Altruism and Trade." World Bank Economic Review 6 (1): 125-38.

Levinsohn, James, and Margaret McMillan. 2007. "Does Food Aid Harm the Poor? Household Evidence from Ethiopia.” In Globalization and Poverty, edited by Ann Harrison, 561-92. Chicago: University of Chicago Press.

Lischer, Sarah Kenyon. 2005. Dangerous Sanctuaries: Refugee Camps, Civil War, and the Dilemmas of Humanitarian Aid. Ithaca: Cornell University Press.

MacFarquhar, Neil. 2010. "Threats Lead Food Agency to Curtail Aid in Somalia." New York Times, January 5, http://www.nytimes.com/201\%1/06/world/africa/06somalia.html.

Matsuura, Kenji, and Cort Willmott. 2007. “Terrestrial Air Temperature and Precipitation: 1900-2006 Gridded Monthly Time Series, Version 1.01.” University of Delaware. http://climate.geog.udel. edu/ climate/html_pages/download.html.

Meernik, James, Eric L. Krueger, and Steven C. Poe. 1998. "Testing Models of U.S. Foreign Policy: Foreign Aid during and after the Cold War." Journal of Politics 60 (1): 63-85.

Miguel, Edward, Shanker Satyanath, and Ernest Sergenti. 2004. "Economic Shocks and Civil Conflict: An Instrumental Variables Approach.” Journal of Political Economy 112 (4): 725-53. 
Montalvo, José G., and Marta Reynal-Querol. 2005. "Ethnic Polarization, Potential Conflict, and Civil Wars." American Economic Review 95 (3): 796-816.

Nickell, Stephen J. 1981. "Biases in Dynamic Models with Fixed Effects.” Econometrica 49 (6): 1417 26.

Nunn, Nathan, and Nancy Qian. 2010. "The Determinants of Food Aid Provisions to Africa and the Developing World.” National Bureau of Economic Research Working Paper 16610.

Nunn, Nathan, and Nancy Qian. 2012. "Aiding Conflict: The Impact of U.S. Food Aid on Civil War." National Bureau of Economic Research Working Paper 17794.

-Nunn, Nathan, and Nancy Qian. 2014. "US Food Aid and Civil Conflict: Dataset." American Economic Review. http://dx.doi.org/10.1257/aer.104.6.1630.

-Pedersen, Karl R. 1996. “Aid, Investment and Incentives.” Scandinavian Journal of Economics 98 (3): 423-38.

Perlez, Jane. 1992. "Somalia Aid Workers Split on Troops.” New York Times, November 27.

Polman, Linda. 2010. The Crisis Caravan: What's Wrong with Humanitarian Aid? New York: Henry Holt and Co.

Qian, Nancy, and David Yanagizawa. 2009. “The Strategic Determinants of U.S. Human Rights Reporting: Evidence from the Cold War." Journal of the European Economic Association 7 (2-3): 446-57.

Qian, Nancy, and David Yanagizawa. 2010. "Watchdog or Lapdog? Media and the U.S. Government." National Bureau of Economic Research Working Paper 15738.

Quisumbing, Agnes R. 2003. "Food Aid and Child Nutrition in Rural Ethiopia." IFPRI FCND Discussion Paper 158.

Rivers, Douglas, and Quang H. Vuong. 1988. "Limited Information Estimators and Exogeneity Tests for Simultaneous Probit Models." Journal of Econometrics 39 (3): 347-66.

Roodman, David. 2007. “An Index of Donor Performance.” Center for Global Development Working Paper No. 67.

Sachs, Jeffrey. 2006. The End of Poverty: Economic Possibilities of Our Time. New York: Penguin Books.

-Stern, Nicholas H. 1974. "Professor Bauer on Development: A Review Article." Journal of Development Economics 1 (3): 191-211.

-Svensson, Jakob. 1999. "Aid, Growth and Democracy.” Economics and Politics 11 (3): $275-97$.

Terry, Fiona. 2002. Condemned to Repeat? The Paradox of Humanitarian Action. Ithaca: Cornell University Press.

Themmer, Lotta, and Peter Wallensteen. 2011. "Armed Conflict, 1946-2010." Journal of Peace Research 48 (4): 525-36.

Thurow, Roger, and Scott Kilman. 2009. Enough: Why the World's Poorest Starve in an Age of Plenty. New York: PublicAffairs.

United Nations Security Council. 2010. "Report of the Monitoring Group on Somalia Pursuant to Security Council Resolution 1853.” http://reliefweb.int/sites/reliefweb.int/files/resources/467A5CB 05AD7E446492576EA0004325D-Full_Report.pdf.

United States Department of Agriculture. Economic Research Service. http://www.ers.usda.gov/Data/ Wheat/ (accessed 2010).

Uvin, Peter. 1998. Aiding Violence: The Development Enterprise in Rwanda. West Hartford, CT: Kumarian Press.

Werker, Eric, Faisal Z. Ahmed, and Charles Cohen. 2009. "How is Foreign Aid Spent? Evidence from a Natural Experiment." American Economic Journal: Macroeconomics 1 (2): 225-44.

- Yamano, Takashi, Harold Alderman, and Luc Christiaensen. 2005. "Child Growth, Shocks, and Food Aid in Rural Ethiopia.” American Journal of Agricultural Economics 87 (2): 273-88. 